OPEN ACCESS

Edited by:

Lars Rogge,

Institut Pasteur, France

Reviewed by:

Jan Niess,

University Hospital of Basel,

Switzerland

Sangwon Kim,

Thomas Jefferson University,

United States

*Correspondence:

Kai Hildner

Kai.Hildner@uk-erlangen.de

${ }^{t}$ Present address:

Vera Buchele,

Department of Transfusion Medicine and Hemostaseology, University Hospital Erlangen, University of Erlangen-Nuremberg, Erlangen,

Germany

Specialty section:

This article was submitted to Cytokines and Soluble Mediators in Immunity, a section of the journal

Frontiers in Immunology

Received: 03 August 2020 Accepted: 08 December 2020 Published: 29 January 2021

Citation:

Buchele $V$, Konein $P$, Vogler $T$, Kunert $T$, Enderle $K$, Khan $H$, Büttner-Herold M, Lehmann CHK,

Amon L, Wirtz S, Dudziak D, Neurath MF, Neufert $C$ and Hildner $K$ (2021) Th17 Cell-Mediated

Colitis is Positively Regulated by Interferon Regulatory Factor

4 in a T Cell-Extrinsic Manner. Front. Immunol. 11:590893. doi: 10.3389/fimmu.2020.590893

\section{Th17 Cell-Mediated Colitis Is Positively Regulated by Interferon Regulatory Factor 4 in a T Cell-Extrinsic Manner}

\author{
Vera Buchele ${ }^{1,2 \dagger}$, Patrick Konein ${ }^{1,2}$, Tina Vogler ${ }^{1,2}$, Timo Kunert ${ }^{1,2}$, Karin Enderle ${ }^{1,2}$, \\ Hanif Khan $^{1,2}$, Maike Büttner-Herold ${ }^{3}$, Christian H. K. Lehmann ${ }^{2,4}$, Lukas Amon ${ }^{2,4}$, \\ Stefan Wirtz ${ }^{1,2}$, Diana Dudziak ${ }^{2,4}$, Markus F. Neurath ${ }^{1,2}$, Clemens Neufert ${ }^{1,2}$ \\ and Kai Hildner ${ }^{1,2 *}$

\begin{abstract}
1 Department of Medicine 1, University Hospital Erlangen, University of Erlangen-Nuremberg, Erlangen, Germany, ${ }^{2}$ Deutsches Zentrum Immuntherapie (DZI), University Hospital Erlangen, University of Erlangen-Nuremberg, Erlangen, Germany, ${ }^{3}$ Institute of Pathology, Department of Nephropathology, University Hospital Erlangen, Erlangen, Germany, ${ }_{4}^{4}$ Laboratory of Dendritic Cell Biology, Department of Dermatology, University Hospital Erlangen, Friedrich-Alexander University of Erlangen-Nuremberg, Erlangen, Germany
\end{abstract}

Inflammatory bowel diseases (IBDs) are characterized by chronic, inflammatory gastrointestinal lesions and often require life-long treatment with immunosuppressants and repetitive surgical interventions. Despite progress in respect to the characterization of molecular mechanisms e.g. exerted by TNF-alpha, currently clinically approved therapeutics fail to provide long-term disease control for most patients. The transcription factor interferon regulatory factor 4 (IRF4) has been shown to play important developmental as well as functional roles within multiple immune cells. In the context of colitis, a T cell-intrinsic role of IRF4 in driving immune-mediated gut pathology is established. Here, we conversely addressed the impact of IRF4 inactivation in non-T cells on $\mathrm{T}$ cell driven colitis in vivo. Employing the $\mathrm{CD} 4^{+} \mathrm{CD} 25^{-}$naïve $\mathrm{T}$ cell transfer model, we found that $T$ cells fail to elicit colitis in IRF4-deficient compared to IRF4-proficient Rag $1^{-/-}$ mice. Reduced colitis activity in the absence of IRF4 was accompanied by hampered T cell expansion both within the mesenteric lymph node (MLN) and colonic lamina propria (cLP). Furthermore, the influx of various myeloids, presumably inflammation-promoting cells was abrogated overall leading to a less disrupted intestinal barrier. Mechanistically, gene profiling experiments revealed a Th17 response dominated molecular expression signature in colon tissues of IRF4-proficient, colitic Rag $1^{-/}$but not in colitis-protected

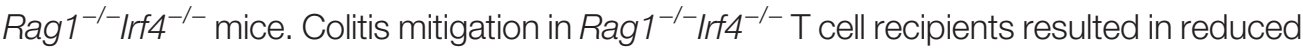
frequencies and absolute numbers of IL-17a-producing T cell subsets in MLN and CLP possibly due to a regulation of conventional dendritic cell subset 2 (CDC2) known to impact Th17 differentiation. Together, extending the T cell-intrinsic role for IRF4 in the 
context of Th17 cell driven colitis, the provided data demonstrate a Th17-inducing and thereby colitis-promoting role of IRF4 through a T cell-extrinsic mechanism highlighting IRF4 as a putative molecular master switch among transcriptional regulators driving immune-mediated intestinal inflammation through both $T$ cell-intrinsic and T cell-extrinsic mechanisms. Future studies need to further dissect IRF4 controlled pathways within distinct IRF4-expressing myeloid cell types, especially cDC2s, to elucidate the precise mechanisms accounting for hampered Th17 formation and, according to our data, the predominant mechanism of colitis protection in $\mathrm{Rag}^{-/-} \mathrm{If4^{-/- }} \mathrm{T}$ cell receiving mice.

Keywords: interferon regulatory factor 4 (IRF4), myeloid cells, Th17, intestinal inflammation, inflammatory bowel disease (IBD)

\section{INTRODUCTION}

Inflammatory bowel diseases (IBDs) clinically manifest with chronic affections of the gastrointestinal tract that are assumed to result from an inadequate immune response while antigens against which the immune attack may be specifically directed have not been identified so far (1). Besides some early-onset cases affecting infants that are due to a rather genetically circumscribed mutation as e.g. IL-10 receptor gene, onset of disease usually occurs in young to middle-aged adults and is triggered by so far rather undisclosed environmental factors that however epidemiologically seem to be associated with western life style habits as e.g. type of nutrition (1-3). Among the diverse and complex pool of immune cell subpopulations found within the inflamed gut of IBD patients, based on many preclinical experimental data sets, $\mathrm{T}$ cells are assumed to play a major pathogenetic role in mediating intestinal tissue inflammation (46). In fact, interleukin 17a (IL-17a) producing T helper (Th17) cells are one of the most prevalent $\mathrm{T}$ cell subsets in the inflamed gut tissue, suggesting a critical contribution to the pathogenesis of IBD (7). However, failure in clinical studies examining the efficacy of antibody mediated IL-17a and IL-17R blockade in IBD was therefore unexpected and may indicate that pro-inflammatory effects of Th17 cells are not or at least not exclusively mediated by the cytokine IL-17a alone with the latter putatively exerting rather barrier-protective effects in this context given the observation of disease aggravation following IL-17a neutralization in some patients $(8,9)$. Regardless, data on the biology and function of IL-23 in IBD argue for the overall colitogenic rather than inflammation-reducing nature of Th17 cells given the fact that IL-23 has been revealed to be one, if not the most important cytokine acting upstream of Th17 cells providing crucial signals for their survival and proliferation (10-13). Interestingly, recently IL-23 which expression is regularly upregulated in IBD tissues was suggested to be critically involved in driving alternative immune pathways specifically active in patients suffering from an antiTNF-alpha blockade resistant disease (14). Overall, in addition to strategies that specifically block gut homing mediating molecules, IL-23 represents together with TNF-alpha one of the few already therapeutically established biological targets in clinical management of IBD further strengthening the case for the central pathogenicity of IL-23R ${ }^{+}$Th17 cells in the context of IBD.
Antigen-presenting cells (APCs) have been identified and characterized to be critical instructors and modulators of both pro- and anti-inflammatory $\mathrm{T}$ cell responses in vivo (15-18). In addition to providing co-stimulatory or -inhibitory signals, APCs do so largely by expressing and releasing cytokines as e.g. IL-12, IL-23, or TGF- $\beta$ all known to be crucial upstream regulators and promoters of pro-inflammatory or regulatory $\mathrm{T}$ cell differentiation programs $(16,17,19,20)$. T cells themselves are unable to express inflammation-promoting cytokines like IL-23 and IL-12. Hence, e.g. IL-23 is largely provided by APC as e.g. dendritic cells and monocytes with the latter shown to have the ability to differentiate into inflammatory dendritic cells in the context of mucosal inflammation (16, 19, 21-23). Dendritic cells are subdivided into conventional (cDCs) and plasmacytoid dendritic cells (pDCs). Based on the developmental dependence on specific transcriptional regulators and critical functional differences in respect to their differential abilities to induce and promote certain types of $\mathrm{T}$ cell responses, $\mathrm{cDCs}$ can be further differentiated into two major subsets, $\mathrm{cDC} 1$ and $\mathrm{cDC} 2$ $(15,24,25)$. cDC1s have been shown to be particularly critical for the induction of anti-viral and anti-tumor $\mathrm{CD}^{+} \mathrm{T}$ cell responses in part by the preferential ability to release IL-12 and CDC1 development is dependent on the transcription factor axis IRF8/BATF3/ID2 (26-29). In contrast, development and functionality of $\mathrm{CDC} 2$ are largely dependent on the transcription factor IRF4 $(16,30,31)$. Interestingly, cDC2s have been shown to represent a critical source for IL-23 expression in vivo suggesting that especially IRF4 dependent cDC2s might represent critical APC driving Th17 cell responses in vivo as e.g. in the context of colitis $(15,16,19)$. While the $\mathrm{T}$ cell-intrinsic function of IRF4 in regard to its contribution to the manifestation of colitis has been thoroughly evaluated (32), the question whether IRF4 expressed by non-T cells is involved in the colitis manifestation and more specifically in the orchestration of the colitogenic $\mathrm{T}$ cell responses and if so in what way has not been studied in great detail so far. Hence, here we assessed the T cell-extrinsic role of IRF4 for the course of acute $\mathrm{T}$ cell driven intestinal inflammation employing the widely accepted $\mathrm{CD} 4^{+} \mathrm{CD} 25^{-}$naïve $\mathrm{T}$ cell transfer model system $(33,34)$. We found that IRF4 expressed in non-T cells is indispensable for the clinical, endoscopic, and histopathological colitis manifestation. Moreover, IRF4 
deficiency within mice receiving IRF4-expressing $\mathrm{T}$ cells resulted in a decreased recovery rate of transferred $\mathrm{T}$ cells both in the draining mesenteric lymph node and the colonic lamina propria. Most importantly, formation of colitogenic $\mathrm{T}$ cells subsets and here foremost IL-17a expressing Th17 cell subsets were severely hampered in the absence of $\mathrm{T}$ cellextrinsic IRF4 expression. Given its established, cell-intrinsic role during the regulation of Th17 fate decision and $\mathrm{CDC} 2$ development and function with the latter known to promote Th17 immune responses, IRF4 overall emerges as a key transcriptional regulator globally promoting Th17 cell driven gut inflammation.

\section{MATERIALS AND METHODS}

\section{Mice}

C57Bl/6 mice were purchased from Janvier Labs, and congenic CD45.1/Ly5.1 B6.SJL-PtrprcaPepcb/BoyCrl mice and B6.PLThy $1^{a} / \mathrm{CyJ}$ mice were purchased from Charles River Laboratories and The Jackson Laboratory, respectively. B6.129S7-Rag1tm1Mom/J (termed $\mathrm{Ragl}^{-/-}$mice) and B6.129P2-Irf4 $4^{\text {tmlMak}} / \mathrm{J}$ (termed Irf4 ${ }^{-/-}$mice) were purchased from The Jackson Laboratory and intercrossed to generate $\operatorname{Rag1}^{-/-} \operatorname{Irf4^{-/-}}$ mice. Mice were maintained under specific pathogen-free conditions. Mice at 8 to 16 weeks of age were used. This study was carried out in accordance with the recommendations of the government of Lower Franconia in Bavaria, Germany. The protocol was approved by the government of Lower Franconia in Bavaria, Germany.

\section{T Cell Transfer Colitis Model}

Splenocytes were isolated from wildtype donor mice (C57Bl/6, CD45.1/Ly5.1 B6.SJL-PtrprcaPepcb/BoyCrl or B6.PL-Thy1 $\left.{ }^{a} / \mathrm{CyJ}\right)$. For this purpose, the spleen was mashed through a $40 \mu \mathrm{m}$ cell strainer and red blood cells were lysed with ACK buffer $(0.15 \mathrm{M}$ $\mathrm{NH}_{4} \mathrm{Cl}, 1 \mathrm{M} \mathrm{KHCO}, 0.8 \mathrm{M} \mathrm{Na}{ }_{2}$ EDTA; pH7.2). Naïve $\left(\mathrm{CD} 4^{+} \mathrm{CD} 25^{-}\right)$splenic $\mathrm{T}$ cells were isolated from spleen cell suspensions by two consecutive magnetic cell separation steps with the $\mathrm{CD}^{+} \mathrm{T}$ cell isolation kit followed by the CD25 Microbead kit (Miltenyi Biotec) according to the manufacturer's instructions. Purity of cell isolates was confirmed by flow cytometry. To induce transfer colitis, $1 \times 10^{6}$ naïve T cells were injected i.p. into recipient mice. Rag1 ${ }^{-/-} \operatorname{Irf}^{-/-}$mice were used as IRF4-deficient recipients. Either Rag1 ${ }^{-/-}$Irf4 ${ }^{+/+}$or Rag1 ${ }^{-/-} \operatorname{Irf4} 4^{+/-}$mice were used as IRF4proficient $\mathrm{T}$ cell recipients due to a virtually indistinguishable colitis phenotype of wildtype $\left(\operatorname{Irf} 4^{+/+}\right)$and IRF4 heterozygous $\left(I r f^{+/-}\right)$mice, and this group is further referred in the manuscript as $\operatorname{Ragl}^{-1-}$ mice.

\section{Mini-Endoscopy of Mice}

Mucosal inflammation of the colon after $\mathrm{T}$ cell transfer was assessed macroscopically by colonoscopy using an image $1^{\mathrm{TM}} \mathrm{S} 3$ mini-endoscope (Karl Storz) as previously described (35). For this purpose, mice were anesthetized and inflammation of the colon was assessed using a modified murine endoscopic index of colitis severity (MEICS) based on four parameters: thickening of the bowel wall, changes of the vascularity, granularity of the mucosal surface and stool consistency. Every parameter was scored from zero for no colitis to three for massive inflammation adding up to a maximal score of 12 as previously described (36).

\section{Histopathological Analysis}

Samples of the distal colon were rinsed with phosphate-buffered saline (PBS; Sigma-Aldrich) and fixed in 4.5\% formaldehyde (Carl Roth) overnight. For histopathological analysis, sections of paraffin-embedded colon tissue were stained with hematoxylin and eosin (H\&E), and inflammation was assessed by a pathologist in a blinded manner based on a slightly modified scoring system described by Erben et al. (37). Slides were analyzed using a Zeiss Axio Imager.A1 microscope and measurements were performed in micrographs taken with a Zeiss AxioCam MRc camera and Zeiss AxioVision (4.9.1.SP2) software. Briefly, histopathological changes were scored for four criteria: inflammatory density $(0=\mathrm{no} / \mathrm{minimal}, 1<10 \%, 2=10$ $25 \%, 3=26-50 \%, 4>50 \%)$, hyperplasia ( $0<200 \mu \mathrm{m}$ crypt length, $1=200-299 \mu \mathrm{m}, 2=300-399 \mu \mathrm{m}, 3>400 \mu \mathrm{m})$, goblet cell loss $(0$ $<20 \%, 1=21-35 \%, 2=36-50 \%, 3>50 \%)$ and crypt abscesses $(0=$ none, $1<$ one, 2 = one to two, $3=$ three or more per quadrant in a circumferential colonic section). In addition, the location of inflammation was assessed ( $1=$ only mucosa, 2 = extending into the submucosa, $3=$ transmural), the crypt loss was scored from 0 to $2(0=$ none, $1=$ one, $2=$ two or more neighboring crypts lost), and the absence or presence of erosion, ulceration and irregular crypts was scored with 0 or 1 , respectively. Scores of each criterion were summed up leading to a maximum total histology score of 21.

\section{Immunohistochemistry}

Samples of the distal part of the colon were frozen and embedded in Optimal Cutting Temperature compound (Sakura). Frozen tissue sections were fixed in $2 \%$ paraformaldehyde for $20 \mathrm{~min}$. To prevent unspecific binding, sections were blocked for $1 \mathrm{~h}$ with blocking buffer consisting of $10 \%$ fetal calf serum (FCS; Pan-Biotech) and 1\% bovine serum albumin (Sigma-Aldrich). Sections were double-stained with anti-F4/80-Alexa Fluor 488 (BM8; BioLegend) and anti-CD4Alexa Fluor 647 (GK1.5; BioLegend) or rabbit anti-MPO (polyclonal; Abcam) in blocking buffer overnight at $4^{\circ} \mathrm{C}$. For MPO staining, sections were additionally incubated with donkey anti-rabbit-IgG-Alexa Fluor 647 (Poly4064; BioLegend) for $2 \mathrm{~h}$ at room temperature in blocking buffer. Nuclei were counterstained with Hoechst 33342 (Life Technologies). Images were recorded using the confocal microscope Leica TCS SP5II with Leica LasX software.

\section{Isolation of Colonic Lamina Propria Cells, Splenocytes, and Mesenteric Lymph Node Cells}

Colonic lamina propria (cLP) cells were isolated by enzymatic digestion as described before (38). Briefly, the colon was rinsed 
with PBS to remove intestinal content, opened longitudinally, and cut into small pieces. After washing colonic pieces twice with Hanks' Balanced Salt solution (HBSS; Sigma-Aldrich) supplemented with EDTA $(0.5 \mathrm{mM})$, intestinal tissue was digested in HBSS containing DNase I $(0.25 \mathrm{mg} / \mathrm{ml})$, collagenase D $(0.5 \mathrm{mg} / \mathrm{ml})$, dispase II (3 Units $/ \mathrm{ml})$, and $5 \%$ FCS. Following filtering through a $40 \mu \mathrm{m}$ cell strainer (Falcon) and washing of the digested tissue with PBS, cLP cells were enriched with density gradient centrifugation where $80 \%$ Percoll was overlaid with cells resuspended in $40 \%$ Percoll (GE Healthcare). cLP cells were washed with RPMI supplemented with $10 \%$ FCS prior to further analysis. Splenocytes and mesenteric lymph node (MLN) cells were isolated by enzymatic digestion of chopped tissues with DNase I (30 U/ $\mathrm{ml})$, collagenase B $(0.25 \mathrm{mg} / \mathrm{ml})$ in DMEM high glucose (Gibco) supplemented with $10 \%$ FCS for $1 \mathrm{~h}$ at $37^{\circ} \mathrm{C}$. Cells were filtered through a $40 \mu \mathrm{m}$ cell strainer and washed with PBS. Red blood cells were lysed with ACK buffer. All enzymes were purchased from Sigma-Aldrich.

\section{Flow Cytometry Analysis}

For the analysis of cell surface markers, isolated cells were stained with fluorochrome-conjugated antibodies dissolved in staining buffer (3\% FCS in PBS) for $20 \mathrm{~min}$ at $4^{\circ} \mathrm{C}$ in the dark before analysis. For staining of intranuclear proteins, the FOXP3 Fix/ Perm buffer set (BioLegend) was used according to the manufacturer's instructions. Briefly, following staining of cell surface markers, cells were fixed in fixation/permeabilization working solution for $40 \mathrm{~min}$ at $4^{\circ} \mathrm{C}$ in the dark before permeabilization and staining in permeabilization buffer for $40 \mathrm{~min}$ at $4^{\circ} \mathrm{C}$ in the dark. For intracellular cytokine staining, isolated cells $\left(1 \times 10^{6} / \mathrm{ml}\right)$ were cultured in cell culture medium [DMEM high glucose containing 10\% FCS, $100 \mathrm{U} / \mathrm{ml}$ penicillin/ $0.1 \mathrm{mg} / \mathrm{ml}$ streptomycin (Sigma-Aldrich), $1 \%$ non-essential amino acids (Sigma-Aldrich), 1\% L-glutamine (Sigma-Aldrich), $1 \mathrm{mM}$ sodium pyruvate (Sigma-Aldrich) and $0.5 \mathrm{mM} \beta$ mercaptoethanol (Gibco)] in the presence of $50 \mathrm{ng} / \mathrm{ml}$ phorbol 12-myristate 13 -acetate (Sigma-Aldrich) and $1 \mu \mathrm{M}$ ionomycin (Sigma-Aldrich) for $4 \mathrm{~h}$ at $37^{\circ} \mathrm{C} .1 \mu \mathrm{g} / \mathrm{ml}$ brefeldin A (SigmaAldrich) was added for the last $3 \mathrm{~h}$ of culture. Thereafter, cells were stained for surface markers. Intracellular cytokine staining was performed as described previously (39). In brief, following fixation with $2 \%$ formaldehyde for $15 \mathrm{~min}$, cells were permeabilized with $0.05 \%$ saponin (Sigma-Aldrich) in staining buffer. Intracellular cytokines were stained for $30 \mathrm{~min}$ at $4^{\circ} \mathrm{C}$ in the dark using fluorochrome-labeled antibodies dissolved in $0.5 \%$ saponin in staining buffer. To identify and exclude dead cells DAPI (Sigma-Aldrich) or the LIVE/DEAD Fixable Aqua Dead Cell Stain Kit (Life Technologies) was used according to the manufacturer's instructions. Stained cells were measured in staining buffer on a FACSFortessa II (BD Biosciences) flow cytometer, and data were analyzed using FlowJo 10.7.1 software (Tree Star Inc). Cell aggregates were excluded from analysis using forward scatter-area versus forward scatter-height scatterplots. The following antibodies were used: anti-Ly6C
(HK1.4), anti-Ly6G (IA8), anti-F4/80 (BM8), anti-CD3e (17A2), anti-CD4 (GK1.5), anti-GM-CSF (MP1-22E9), anti-IL17a (TC11-18H10.1), anti-IFN- $\gamma$ (XMG1.2); anti-CD45.2 (104), anti-I-A/I-E (M5/114.15.2), anti-CD11c (N418), anti-CD103 (2E7), anti-CD11b (M1/70), anti-IRF-4 (IRF4.3E4), antiCD172 (A7R34), anti-T-bet (4B10), anti-XCR1 (ZET), streptavidin-Brilliant-Violet 421 from BioLegend, anti-CD11b (M1/70), anti-ROR $\gamma$ (Q31-378), anti-I-A/I-E (M5/114.15.2), anti-CD45 (30F11), anti-CD19 (1D3), anti-CD3 $\epsilon$ (17A2), antiNK1.1 (PK136), anti-CD11c (HL3) from BD Biosciences, AntiCD172a (P84) from Life Technologies, anti-Thy1.2 (30-H12), anti-GATA3 (REA174) and a custom made biotinylated lineage antibody cocktail (anti-B220, anti-CD3, anti-CD5, anti-CD11b, anti-GR1, anti-NK1.1, anti-SiglecF, anti-Ter119) from Miltenyi Biotec.

\section{Quantitative Real-Time Polymerase Chain Reaction}

Following RNA isolation from a sample of distal colonic tissue using the NucleoSpin RNA isolation kit (Macherey Nagel), cDNA of $1 \mu \mathrm{g}$ RNA was reverse transcribed using iScript cDNA Synthesis kit (Bio-Rad Laboratories). RNA quality and concentration were measured with a Nanodrop ND-1000 (Thermo Fisher Scientific). Gene expression was measured by quantitative Real-Time polymerase chain reaction (qPCR) using iQ SYBR Green Supermix (Bio-Rad Laboratories) and the following primers (MWG Eurofins): Hprt forward 5'-TGG ATA CAG GCC AGA CTT TGT T-3', reverse 5'-CAG ATT CAA CTT GCG CTC ATC-3', Ifng forward 5'-ATC TGG AGG AAC TGG CAA AA-3', reverse 5'-TGA GCT CAT TGA ATG CTT GG-3', Csf2 forward 5'-ATC AAA GAA GCC CTG AAC CT-3', reverse 5'-GTG TTT CAC AGT CCG TTT CC-3', Tnf forward 5'-CTT GTG GCA GGG GCC ACC AC-3', reverse 5'CCA TGC CGT TGG CCA GGA GG-3', Il-17a forward 5'-GCT CCA GAA GGC CCT CAG A-3', reverse 5'-AGC TTT CCC TCC GCA TTG A-3', Ill b forward 5'-GTG ACG TTC CCA TTA GAC AA-3', reverse 5'-TAT TTT GTC GTT GCT TGG TT-3', Rorc forward 5'-CCG CTG AGA GGG CTT CAC-3', reverse 5' TGC AGG AGT AGG CCA CAT TAC A-3', Il23r forward 5' CAC AAC AAC TAC ACG TCC AT-3', reverse 5'-TAC CAG TTT CTT GAC ATC GC-3', Batf forward 5'-GGA AGA TTA GAA CCA TGC CTC-3', reverse 5' -CCA GGT GAA GGG TGT CGG-3', Il6 forward 5'-CCG GAG AGG AGA CTT CAC AG-3', reverse $5^{\prime}$-TTC TGC AAG TGC ATC ATC GT-3', Il12a forward 5'-ACA GGG TGA TGG GCT ATC TG-3', reverse 5'-GGG GAG ATG AGA TGT GAT GG-3', Il23r forward 5' -CAC AAC AAC TAC ACG TCC AT-3', reverse 5'-TAC CAG TTT CTT GAC ATC GC-3'. Primer sets for Tbx21 and Il23a were purchased from QIAGEN. Samples were run on a CFX Connect and CFX96 RealTime PCR detection system (Bio-Rad Laboratories). Data were analyzed with CFX Manager v3.1 (Bio-Rad Laboratories). Expression levels of target genes for each sample were normalized relative to the reference gene Hprt. Relative gene expression levels were calculated with the $2\left(^{-\Delta \Delta \mathrm{Ct}}\right)$ method. Mean gene expression levels detected in $\mathrm{Ragl}^{-1-}$ mice were arbitrarily set to one and gene expression levels of Rag $^{-/-}$Irf $4^{-/-}$ 
mice were calculated and displayed in relation to the normalized $\operatorname{Rag1}^{-/-}$mice.

\section{Statistical Analysis}

Unpaired Student's $t$ test was used for comparison of means of two datasets. ${ }^{*} p<0.05$ was considered to be significant. Statistical analysis was performed with Graphpad Prism 8.3.0 software.

\section{RESULTS}

\section{Rag1 $^{-/}$Irf4 ${ }^{-/-}$Mice Fail to Develop Colitis Upon Transfer of Naïve CD4 ${ }^{+}$T Cells}

Previously, we and others have reported that in the $\mathrm{T}$ cell transfer colitis model inflammatory manifestations within the gut are strongly dependent on $\mathrm{T}$ cell-intrinsic expression of transcription factors proven to be indispensable for the differentiation of Th17 cells in vitro and in vivo $(32,40-42)$. In line with that, $\mathrm{T}$ cell restricted IRF4-deficiency severely compromised T cells' ability to induce colitis (32). Conversely, however, the selective role IRF4 expressed by non-T cells exerts in the immune pathogenesis of colitis remains largely unresolved. To decipher the unknown impact of IRF4 in this setting, we sought to create a genetic model in which IRF4 deficiency is restricted to the non-T cell compartment while $\mathrm{T}$ cells remain fully competent, i.e. T cells with preserved IRF4 expression abilities. In this experimental set-up, any kind of regulation of observed $\mathrm{T}$ cell colitogenicity would be secondary to the T cell-extrinsic IRF4 deficiency, i.e. clearly attributable to the altered functionality of non-T cells in the absence of IRF4. Thereby, this data set was suitable to help define the T cell-extrinsic role of IRF4 in the context of colitis. To achieve this goal, we crossed IRF4 germline deficient mice onto the Rag1-deficient background and elicited colitis in these mice upon naïve $\mathrm{CD} 4^{+} \mathrm{T}$ cell transfer into

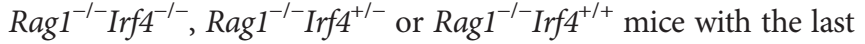
two groups serving as IRF4-sufficient control animals (termed Rag1 $1^{-1-}$ mice) $(33,34,43)$. Strikingly, as documented by the dynamic changes of the body weight curves over time, after 7-10 days, i.e. upon completion of priming and start of substantial expansion of transferred CD4 ${ }^{+} \mathrm{T}$ cells, IRF4-proficient recipient mice started to lose initially subtly but progressively increasing weight compared to IRF4-deficient $R a g 1^{-/-}$mice with a clear separation of both curves at the beginning of the fourth week after experimental start (Figure 1A).

To assess whether the observed weight loss is accompanied by or even due to an acute immune-mediated affection of the colonic barrier, we performed mini-endoscopic evaluation of the distal colon of both IRF4-sufficient and -deficient Rag1 $1^{-/-}$ mice in vivo prior sacrificing mice (Figure 1B). As displayed in Figure 1B, at this time point colonoscopy showed that IRF4competent mice suffered from severe colitis in respect to all evaluated categories adding up to a mean sum score of around 8. In contrast, $\mathrm{T}$ cell receiving $\mathrm{Ragl}^{-1-}$ mice deficient in IRF4 virtually lacked macroscopic signs of colitis evidenced by a sum score of $<3$ with a score of $\geq 3$ representing the empiric cut-off value for mice suffering from clinically meaningful, endoscopic signs of colitis. To further validate the macroscopic results, we performed thorough histopathological studies by evaluating cross-sections derived from the distal colon, i.e. areas matching the mini-endoscopically assessed region (Figure 1C). Here, histopathological scoring and grading revealed that both goblet cell loss and crypt length increase commonly observed following severe forms of intestinal inflammation were decreased in $\mathrm{Ragl}^{-1-} \operatorname{Irf4^{-1-}} \mathrm{T}$ cell receiving mice. Overall, histopathologically assessed parameters summarized in the histology score underscore and further extend the results obtained during endoscopic evaluation that $\mathrm{Rag}^{-/-}$mice lacking IRF4 expression are largely protected from $\mathrm{T}$ cell mediated colon inflammation (Figure 1C). Overall data presented so far unequivocally demonstrate that IRF4 expression within non-T cells is indispensable for $\mathrm{T}$ cell mediated transfer colitis in $\mathrm{Ragl}^{-1-}$ recipient mice based on both clinical, endoscopic, and histopathological scoring results.

\section{Colitis Protection of IRF4 Deficient Rag1 $^{-/-}$Mice Is Associated With a Reduced Expansion of Transferred T Cells and Diminished Recruitment of Inflammatory Mononuclear Cells Into the Colon}

To further deconstruct the mechanism underlying reduced manifestation of intestinal inflammation in $\mathrm{Ragl}^{-1} \mathrm{Irf4^{-1- }}$ mice when compared to controls, we next focused on the quantitative and qualitative regulation of the cellular composition within the inflamed gut. First, we performed multi-color immunofluorescence (IF) staining of distal colon cross-sections matching previously histopathologically assessed areas (Figure 2A). We readily observed a striking reduction of the total immune cell infiltration in Rag $^{-/-}$mice lacking IRF4 expression. In line with our IF data, cell number calculations of isolated colonic lamina propria mononuclear cell preparations confirmed a significant reduction of total cLP cells in mice lacking IRF4 compared to IRF4-sufficient controls (Figure 2B). Furthermore IF imaging suggested that transferred $\mathrm{CD} 4^{+} \mathrm{T}$ cells are less abundant in $\mathrm{Ragl}^{-/-} \mathrm{Irf4^{-/ }}$ mice compared to controls, and this finding was further substantiated by additional flow cytometry-based enumeration of $\mathrm{CD}^{+} \mathrm{T}$ cells within the total live cLP-derived immune cell pool (Figures 2A, B). To further dissect whether this observation results from a general reduction of $\mathrm{T}$ cell activation/ proliferation or is rather due to a gut homing phenotype due to hampered migratory properties of the T cells in the absence of IRF4 expression in non-T cells, we determined both the total cellularity and relative fraction of $\mathrm{T}$ cells within the mesenteric lymph node (MLN) cells by flow cytometry. Interestingly, similar to the cLP compartment, total numbers of MLN residing immune cells were reduced in $\mathrm{Ragl}^{-/-} \mathrm{Irf4^{-/- }}$ mice compared to controls (Figure 2B). Also, the absolute numbers of $\mathrm{CD}^{+} \mathrm{T}$ cells were significantly diminished within the MLN suggesting that at least to a certain degree hampered systemic $\mathrm{T}$ cell activation and expansion may account for the lack of a colitis-mediating $\mathrm{T}$ cell pool in the absence of T cell-extrinsic IRF4 expression. However, despite that finding, the fraction of $\mathrm{CD}^{+} \mathrm{T}$ cells within the MLN residing immune cell pool 


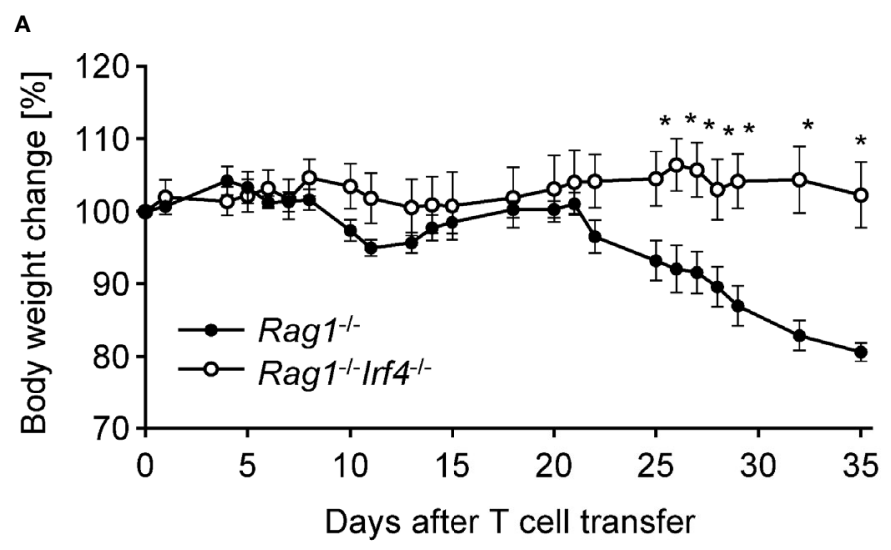

B
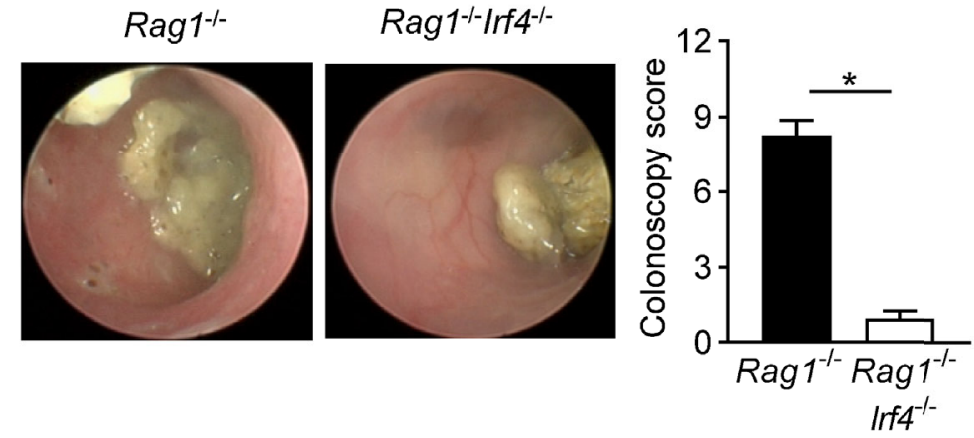

$\operatorname{Rag} 1 \%$

$\operatorname{Rag} 1^{-1-} \mid \mathrm{rf} 4^{-1-}$
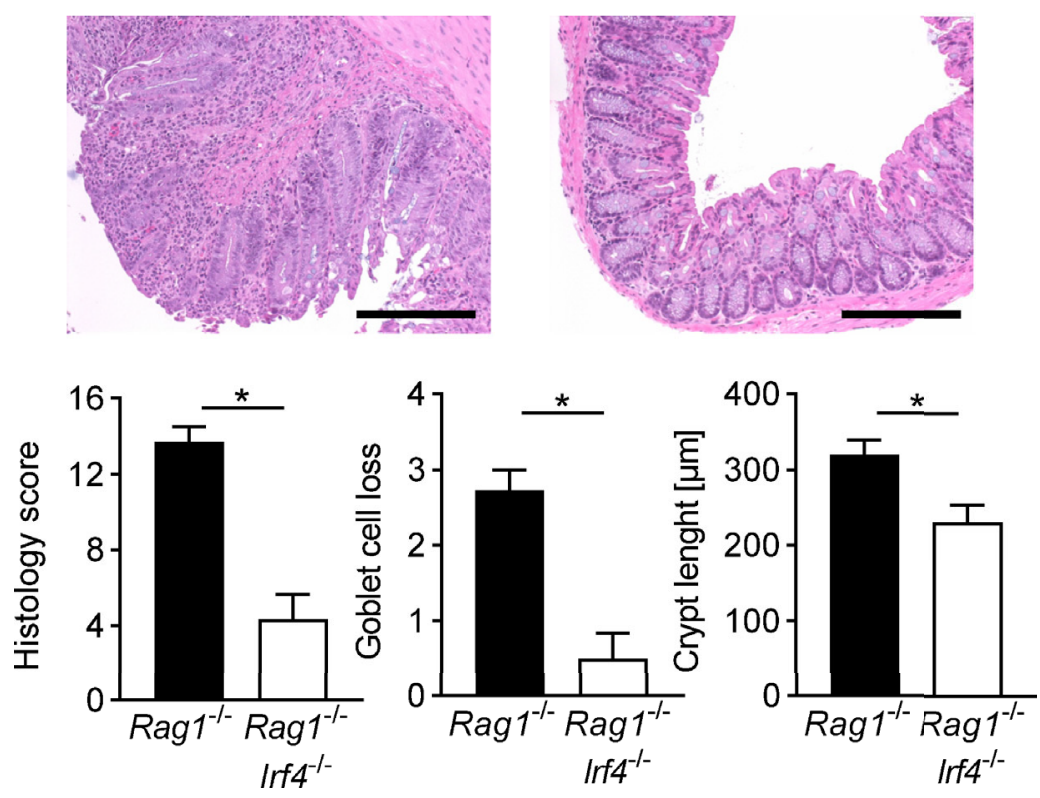

FIGURE 1 | Inactivation of IRF4 in non-T cells abrogates clinical, endoscopic, and histopathological signs of colitis. At day 0 Rag $1^{-/-}$and Rag $1^{-/-}$IIf $4^{-/-}$mice were injected i.p. with $1 \times 10^{6}$ nairve $\left(C D 4^{+} \mathrm{CD} 25^{-}\right) \mathrm{T}$ cells. (A) Percentage body weight changes compared to the original body weight at day 0 were assessed over time. A representative course of body weight changes per experimental group from one of four experiments is shown (Rag $1^{-/-} n=6$; Rag $\left.1^{-/-} I r 4^{-/-} n=5\right)$. (B) Colitis severity was analyzed by colonoscopy when T cell recipient Rag $1^{-/-}$mice showed sustained weight loss of more than $10 \%$ of their initial body weight for at least one week (four to five weeks after T cell transfer). Colonoscopy score of three independent experiments and representative endoscopic images for every experimental group are shown. Rag $1^{-/-}$and Rag $1^{-/-}$Iff $4^{-/-}$mice were sacrificed when colitis was established in T cell recipient Rag $1^{-/-}$mice identified by weight loss and colonic inflammation via colonoscopy (five to six weeks after T cell transfer). (C) Histopathological scoring of the inflammation present in the distal colon. One representative H\&E-stained histopathological cross-section of the distal colon per group is shown. Scale bars: $100 \mu \mathrm{m}$. (B, C) Data are combined from three individual experiments

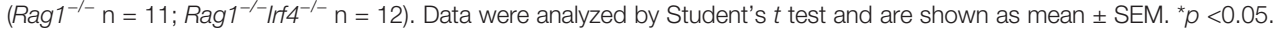


was even relatively increased compared to control mice (Figure 2B). Hence, hampered efflux of $\mathrm{CD}^{+} \mathrm{T}$ cells from the MLN due to incomplete priming and/or imprinting of gut homing properties may be also contributing to the reduced representation of colitogenic $\mathrm{T}$ cells in the cLP fraction.

Intestinal myeloid cells have been described to play a dichotomic, context-dependent role under homeostatic and inflammatory conditions by exerting both anti-inflammatory as well as pro-inflammatory functions $(22,23,44)$. Especially bloodderived monocytes are recruited to the gut through signal cascades initially set in motion by the intestinal immigration of cytokine releasing effector $\mathrm{T}$ cells where they were shown to at least partially convert into cells displaying a Ly6C ${ }^{\text {hi }}$ inflammatory phenotype (4547). In fact, IF studies exploring the expression pattern of the surface glycoprotein and myeloid marker F4/80 revealed that colonic tissues of $\mathrm{T}$ cell receiving $\mathrm{Rag}^{-1-} \mathrm{Irf4^{-/- }}$ mice contained visibly reduced F4/80 expressing cells compared to controls contrasting the virtually indistinguishable pattern of $\mathrm{F} 4 / 80^{+}$and/or $\mathrm{MPO}^{+}$cells resp. in the absence of inflammation between IRF4 proficient $v s$. deficient mice (Figure 2A, Supplementary Figure 1A). Further resolution in regard to the cellular composition of the $\mathrm{F} 4 / 80^{+}$cells was provided by additional in-depth flow cytometry analyses of cLP cell fractions. With the help of the shown gating strategy starting of $\mathrm{CD} 1 \mathrm{~b}^{+}$cells, we are able to distinguish F4/80 ${ }^{+} \mathrm{Ly}_{6 \mathrm{G}}{ }^{\text {neg }} \mathrm{SSC}^{\text {low }} \mathrm{Ly} 6 \mathrm{C}^{\text {high }}$ inflammatory monocytes from $\mathrm{F} 4 / 80^{+} \mathrm{Ly} 6 \mathrm{G}^{\text {neg }} \mathrm{SSC}^{\text {low }} \mathrm{Ly} 6 \mathrm{C}^{\text {neg }}$ eosinophils and F4/80 ${ }^{\text {neg }} \mathrm{Ly} 6 \mathrm{C}^{+} \mathrm{Ly}_{6 \mathrm{G}}{ }^{+}$neutrophils (Figure 2C). Employing this gating approach, we readily found that the fraction of $\mathrm{CD} 11 \mathrm{~b}^{+}$ cells is dramatically increased within the pool of live cLP cells derived from $\mathrm{T}$ cell treated $\mathrm{Rag} 1^{-/-}$mice with intact IRF4 expression compared to IRF4-deficient mice (Figure 2C). Moreover, we found that mononuclear cell isolates from the cLP compartment contained both absolutely and relatively diminished fractions of both neutrophils, eosinophils and presumably inflammatory Ly6C $\mathrm{C}^{\text {high }}$ monocytes in $\mathrm{Ragl}^{-/-}$mice lacking IRF4 expression compared to IRF4-proficient controls (Figure 2C). In contrast, neither absolute nor relative IRF4-dependent regulation of either cell population prior $\mathrm{T}$ cell transfer, i.e. non-inflamed mice was detectable (Supplementary Figure 1B). Finally, similar to our studies on the $\mathrm{T}$ cell phenotype shown above in Figures 2A, B, we compared the composition of the MLN resident myeloid cell compartment in

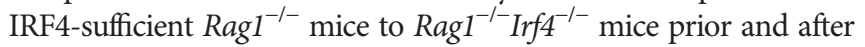
$\mathrm{T}$ cell transfer. We could not detect any relative or absolute IRF4dependent difference within granulocyte subsets and Ly6C ${ }^{\text {high }}$ monocytes in the absence of $\mathrm{T}$ cell induced colitis (Supplementary Figure 1C). Moreover, however contrasting our studies on the cLP compartment, the relative fractions of MLN residing neutrophils, eosinophils, and inflammatory monocytes were not increased in IRF4-competent compared to IRF4-deficient $\mathrm{Rag1}^{-/-}$mice after T cell transfer (Figure 2D). In addition, absolute numbers of neutrophils were virtually indistinguishable between $\mathrm{T}$ cell receiving $\mathrm{Ragl}^{-1-}$ mice irrespective of their ability to express IRF4. However, in contrast, both absolute eosinophil as well as Ly6 $\mathrm{C}^{\text {high }}$ monocyte counts were significantly reduced in MLN of $\operatorname{Ragl}^{-1-} \operatorname{Irf4^{-1-}}$ mice compared to controls (Figure 2D). In summary, our data so far suggest that $\mathrm{T}$ cell-extrinsic inactivation of IRF4 leads to hampered T cell expansion both in MLN and cLP, while defective MLN exiting and/or gut homing abilities might add to the overall reduced recovery of putatively colitogenic cLP $\mathrm{T}$ cells. Furthermore, recruitment and/or local, i.e. intestinal expansion of neutrophils, eosinophils and Ly6 $\mathrm{C}^{\text {high }}$ monocytes are severely compromised upon $\mathrm{T}$ cell transfer in $\mathrm{Rag}^{-1-}$ mice lacking IRF4 expression compared to IRF4 competent controls.

\section{IRF4 Induces a Colonic Th17 Gene Expression Signature in T Cell-Driven Colitis}

Our results have so far established that IRF4 controls the expansion of transferred $\mathrm{T}$ cells and recruitment of a series of putatively pro-inflammatory acting myeloid cells in $\mathrm{T}$ cell mediated acute colitis through a $\mathrm{T}$ cell-extrinsic mechanism. To gain further insight into the molecular mechanism and tissue micromilieu acting in the colitic tissue on the immune cell network, we performed quantitative gene expression analyses employing a series of markers affiliated to distinct $\mathrm{T}$ helper cell subsets (Figure 3). As displayed in Figure 3A, expression of the prototypical Th1 cytokine IFN-gamma was not differentially expressed between IRF4-competent vs. -deficient Rag1 $^{-/-} \mathrm{T}$ cell recipient mice despite a trend towards reduced expression in the absence of IRF4. However, in contrast, colonic expression levels of IL-17, GM-CSF and TNF-alpha were significantly reduced in the absence of IRF4 compared to controls suggesting hampered representation of a Th17 cell enriched cytokine milieu in situ. To specifically assess whether Th17 cell differentiation inducing and/or Th17 cell promoting cytokines are differentially regulated, we compared colonic gene expression profiles of IL12 (Th1) and IL-1 $\beta /$ IL-6/IL-23 (Th17) between colitis-protected Rag1 $^{-1-}$ Irf4 ${ }^{-/-}$and colitic IRF4-competent mice (Figure 3B). With the exception of Il23a, i.e. IL-23p19 the colonic tissue expression of all molecules was significantly reduced in the absence of IRF4 clearly indicating that IRF4 expressed by non$\mathrm{T}$ cells might be critical for the generation of a Th17 prone microenvironment. In line with a predominately Th17 differentiation permitting tissue micromilieu, additional quantification of total IL-23R expression revealed significantly upregulated tissue levels in the presence of $\mathrm{T}$ cell extrinsically expressed IRF4 (Figure 3B). Overall enhanced IL-23R expression might indicate increased susceptibility of invading immune cells including $\mathrm{T}$ cells to be permissive for IL-23 mediated effects as Th17 cell differentiation and/or expansion. Since our data so far clearly suggested that molecules and pathways feeding into Th17 cell rather than Th1 cell differentiation are positively regulated by IRF4 through a $\mathrm{T}$ cell-extrinsic mechanism, we finally assessed tissue expression levels of transcription factors firmly connected to Th1 and Th17 differentiation, respectively (Figure 3C). Interestingly, tissue Tbet/Tbx21 expression widely accepted to be a critical regulator of Th1 differentiation was virtually indistinguishable between both Rag1 $1^{-/-}$cohorts irrespective of their ability to express IRF4 or not (48). In contrast, however, and in full agreement with the data presented above (Figures $3 \mathbf{A}, \mathbf{B}$ ), $\operatorname{Rag} 1^{-/-}$mice deficient in IRF4 
A

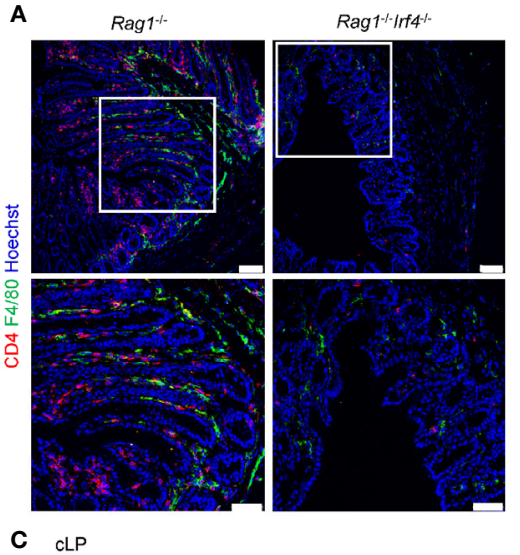

B
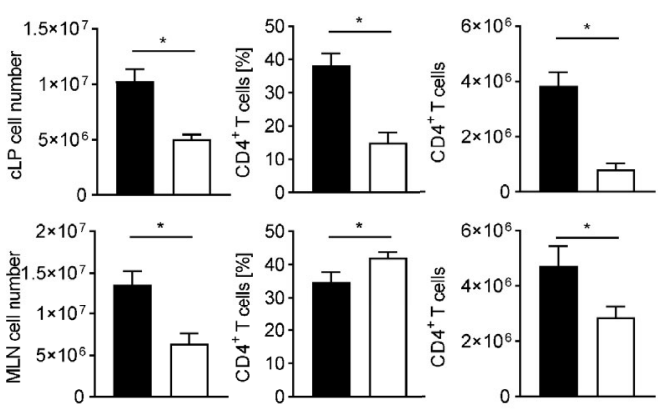

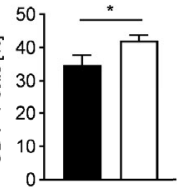

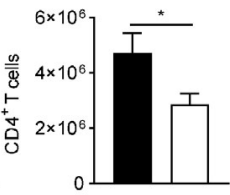

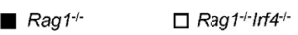
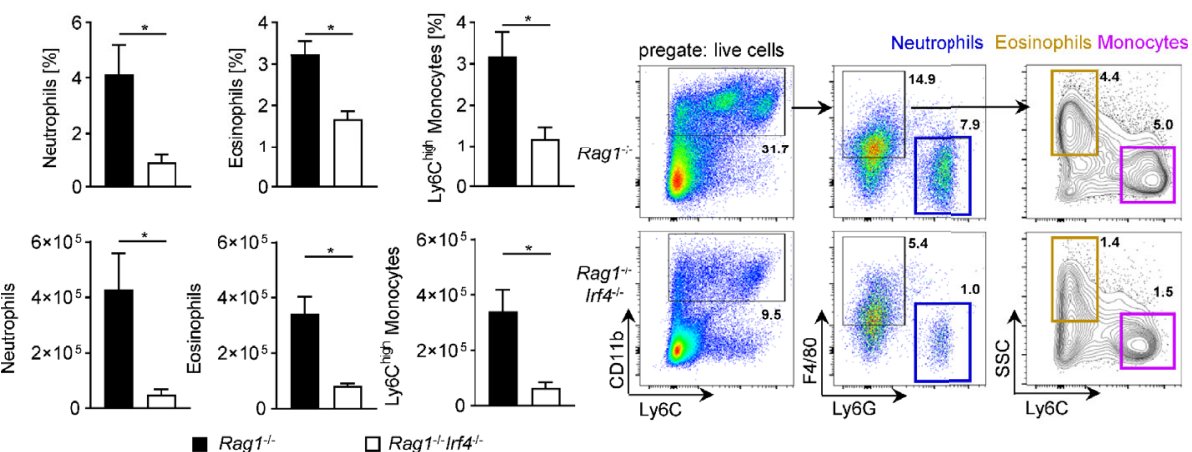

- Rag $1^{\text {th }}$

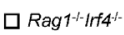

D MLN

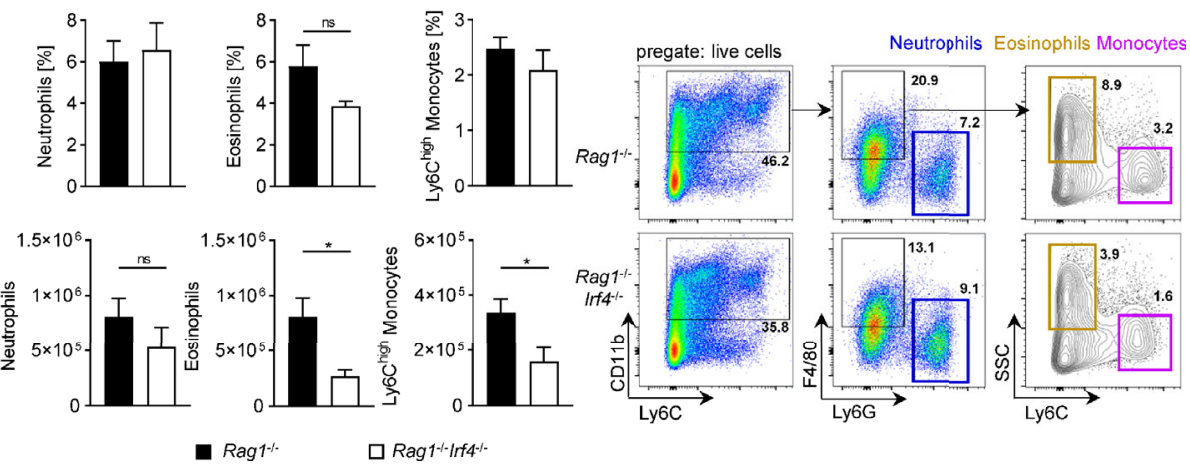

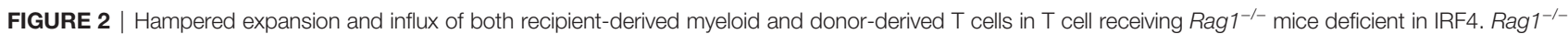
and $R a g 1^{-/-} I r 4^{-/-}$mice were injected i.p. with $1 \times 10^{6}$ naïv $\left(\mathrm{CD}^{+} \mathrm{CD} 25^{-}\right) \mathrm{T}$ cells. When colitis was established in Rag ${ }^{-/-}$mice five to six weeks after T cell transfer,

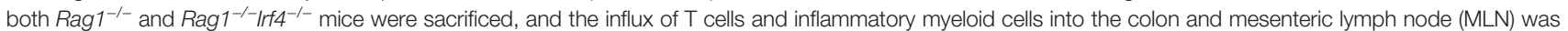
analyzed. (A) Representative immunofluorescence staining of $\mathrm{F} 4 / 80^{+}$and $\mathrm{CD}^{+}$cells in colonic cross sections at day 39 after T cell transfer. Upper panel: overview picture of the colonic tissue (scale bars $=75 \mu \mathrm{m}$ ); lower panel: higher magnification of the white boxed area within the colonic tissue of the upper panel (scale bars = $50 \mu \mathrm{m}$ ). (B) Absolute number of colonic lamina propria (cLP) and MLN was determined (left column). Frequencies (middle column) and absolute numbers (right column) of $\mathrm{CD} 4^{+} \mathrm{T}$ cells $\left(\mathrm{CD}^{+} \mathrm{CD}^{+}\right)$within the total live immune cell pool were analysed by flow cytometry. In addition relative fraction (upper panel) and absolute

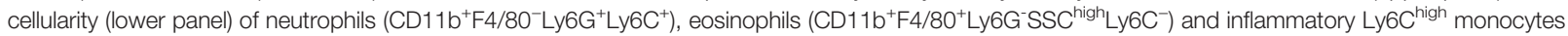
$\left(\mathrm{CD}_{11} \mathrm{~b}^{+} \mathrm{F} 4 / 80^{+} \mathrm{Ly}_{6 \mathrm{G}} \mathrm{SSSC}^{\text {low }}\right.$ Ly6C high) within the total live immune cell pool of $\mathrm{CLP}$ (C) and MLN (D) cells were analyzed by flow cytometry. One representative flow cytometry plot is shown for every experimental group and illustrates the gating strategy for the indicated cell populations. Frequencies of cells in each sub-gate are

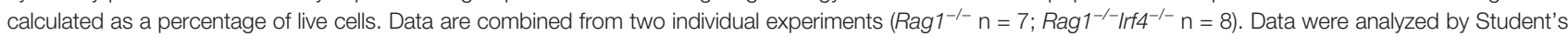
$t$ test and are shown as mean \pm SEM. ns, not significant. ${ }^{*} p<0.05$.

showed a significantly reduced tissue expression of bona fide Th17 regulating transcription factors ROR $\gamma$ and $\operatorname{BATF}(39,49)$. Collectively, our data demonstrate that IRF4 expression by non$\mathrm{T}$ cells in $\mathrm{T}$ cell receiving $R a g 1^{-1-}$ mice is crucial for the establishment of a Th17 prone microenvironment in the colon suggesting that IRF4 may control T cell mediated colitis through provision of Th17 cell differentiation enabling and promoting mechanisms outside of $\mathrm{T}$ cells. 


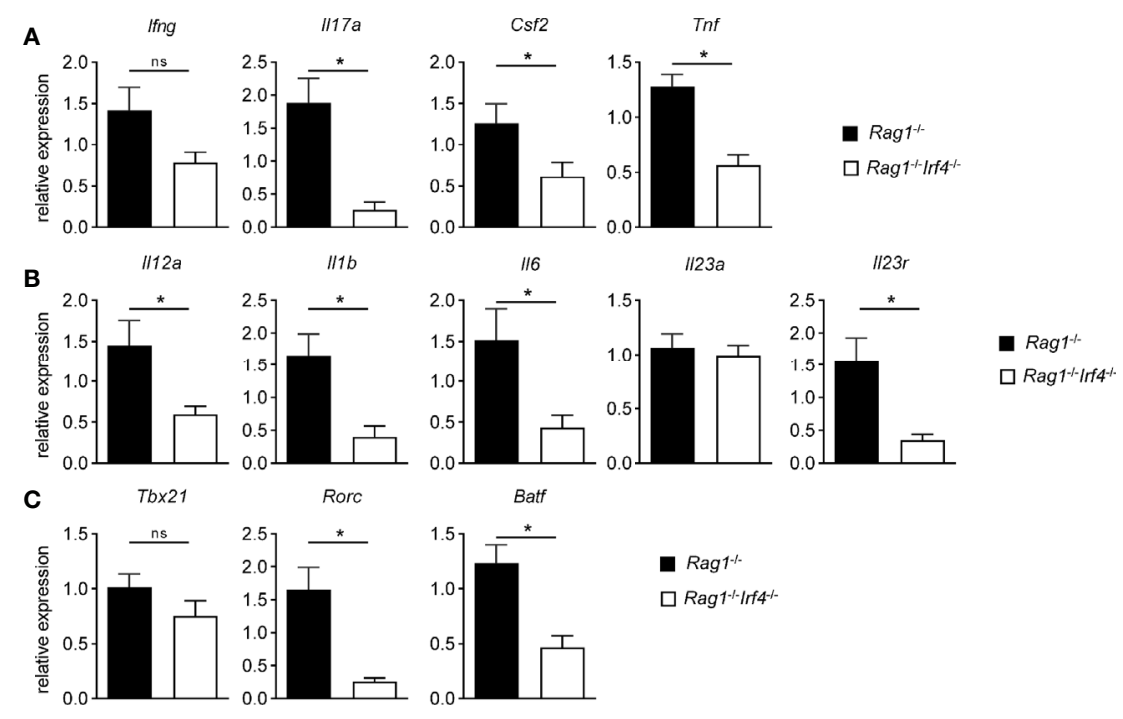

FIGURE 3 | IRF4 drives a pro-inflammatory, Th17 cell differentiation promoting and putatively presence of functional Th17 cells increasing molecular gene expression signature in colitis tissues in a T cell-extrinsic manner. Rag $1^{-1-}$ and Rag $1^{-/-} I r 4^{-/-}$mice were injected i.p. with $1 \times 10^{6}$ naïve $\left(\mathrm{CD} 4^{+} \mathrm{CD} 25^{-}\right) \mathrm{T}$ cells. When colitis was established in Rag $1^{-/-}$mice five to six weeks after T cell transfer, both Rag $1^{-/-}$and Rag $1^{-/-} / \mathrm{rf} 4^{-/-}$mice were sacrificed. Gene expression levels of (A) Ifng, I/17a, Csf2, Tnf, (B) $/ 112 a,\|1 b\| 6,,\|23 a\|$,$23 r , (C) Tbx21, Rorc, and Batf transcripts within colonic tissue were analyzed and quantitated by qPCR. Mean of gene$ expression levels detected in colonic tissues of Rag $1^{-/}$mice was arbitrarily set down to 1, and all other gene expression levels were normalized to the expression

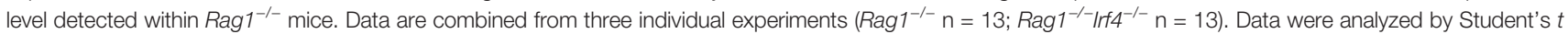
test and are shown as mean \pm SEM. ns, not significant. ${ }^{*} p<0.05$.

\section{IRF4 Is Indispensable for the Formation, Expansion, and Intestinal Homing of Th17 but Not Th1 Cells in a T Cell-Extrinsic Manner}

To further test our hypothesis that missing IRF4 expression within non-T cells results in the abrogated formation of colitogenic Th17 cells and that this step is critical as it may mainly account for alleviated colitis manifestation in this group, we performed in-depth intracellular cytokine staining profiling experiments employing flow cytometry (Figure 4). To achieve this goal, following ex vivo restimulation we stained both MLN and CLP derived CD4 ${ }^{+} \mathrm{T}$ cells for IFN-gamma, IL-17a, and GMCSF expression and compared frequencies of Th1 and Th17 subsets resp. between $\operatorname{Rag} 1^{-/-} \operatorname{Irf4^{-/-}}$ and IRF4-sufficient control mice. In accordance with our gene expression profiling experiments, T-bet dependent Th1 cells defined as IFNgamma ${ }^{+} \mathrm{IL}-17 \mathrm{a}^{-} \mathrm{T}$ cells were detected irrespective of the presence or absence of IRF4 expression and hence appear to develop independent of T cell-extrinsic IRF4 expression (Figures $\mathbf{4 A}, \mathbf{B})$. In sharp contrast, however, IL-17a producing $\mathrm{T}$ cell subsets including IL-17a single producing as well as IL-17a ${ }^{+} \mathrm{T}$ cells co-expressing either IFN-gamma or GM-CSF were broadly negatively affected in mice lacking $\mathrm{T}$ cell-extrinsic IRF4 expression (Figures 4A, B). Strikingly, the comparison of both MLN and CLP displayed an unequivocal pattern across organs in the absence of T cell-extrinsic IRF4 expression overall supporting the conclusion that reduced Th17 cell fractions in these mice reflect a rather general negative effect on Th17 cell differentiation and eventually Th17 cell pool than merely results from hampered colonic influx of in MLN otherwise appropriately skewed and functionally equipped Th17 cells.

Finally, to shed light on the mechanism putatively underlying altered $\mathrm{T}$ cell instruction and proliferation in the absence of IRF4, we screened for IRF4-dependent changes in the colonic innate immune cell pool in the steady state, i.e. prior $\mathrm{T}$ cell transfer. In regard to innate lymphoid cells (ILC) with presumably overall rather colitis-suppressive effects given the fact that ILC depletion leads to enhanced colitis manifestation $(50,51)$, we found that the colonic pool of ILC1, ILC2, and ILC3 forms in a virtually IRF4 expression independent manner (Supplementary Figure 2). Next, we assessed the antigenpresenting cell (APC) compartment in $\mathrm{Ragl}^{-/-}$vs. Rag1 ${ }^{-}$Irf4 ${ }^{-/-}$mice (Supplementary Figure 3 ). In support of the possibility that IRF4 deficient APCs may primarily account for the observed reduced ability to skew transferred naïve $\mathrm{T}$ cells into colitogenic Th17 cells, we confirmed data from previous reports $(15,16,24)$ by demonstrating that the pool of Th17 responses promoting $\mathrm{CDC} 2 \mathrm{~s}$ but not $\mathrm{CDC} 1 \mathrm{~s}$ is reduced in the absence of IRF4 both in the spleen and MLN (Supplementary Figures 3A, B). Although, colonic DC populations were not regulated in the absence of IRF4 (Supplementary Figure 3C), flow cytometric expression profiling among colonic APCs interestingly revealed that predominately $\mathrm{CD}_{1} 1 \mathrm{~b}^{+} \mathrm{cDCs}$, i.e. $\mathrm{cDC} 2 \mathrm{~s}$ regulated in both $\mathrm{MLN}$ and spleen, express higher levels IRF4 protein compared to $\mathrm{CD}_{103}{ }^{+} \mathrm{CD} 11 \mathrm{~b}^{-} \mathrm{cDC} 1$ (Supplementary Figure 3D). This result implies that albeit 
A MLN CD3 ${ }^{+} \mathrm{CD} 4^{+} \mathrm{T}$ cells
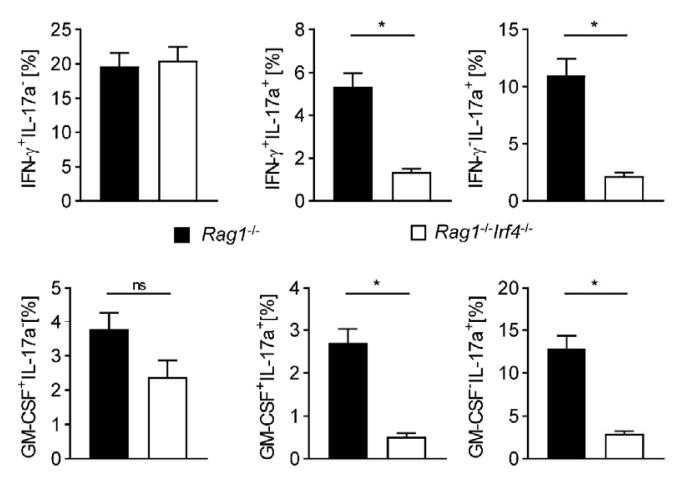

B $\operatorname{cLP~CD3} 3^{+} \mathrm{CD} 4^{+} \mathrm{T}$ cells
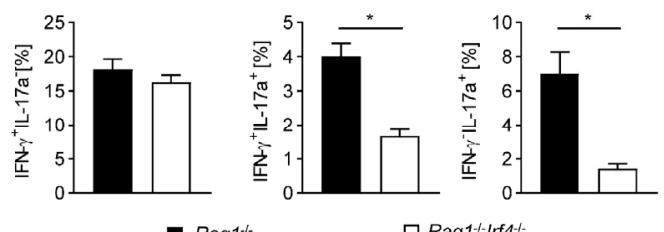

$\square \operatorname{Rag}^{1-1-I} \ln 4^{-1-}$
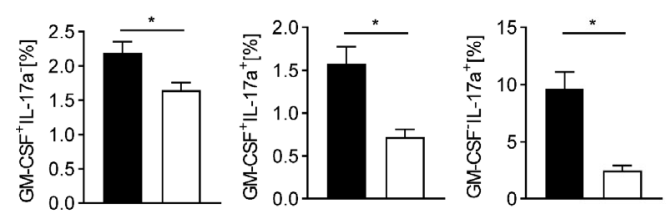
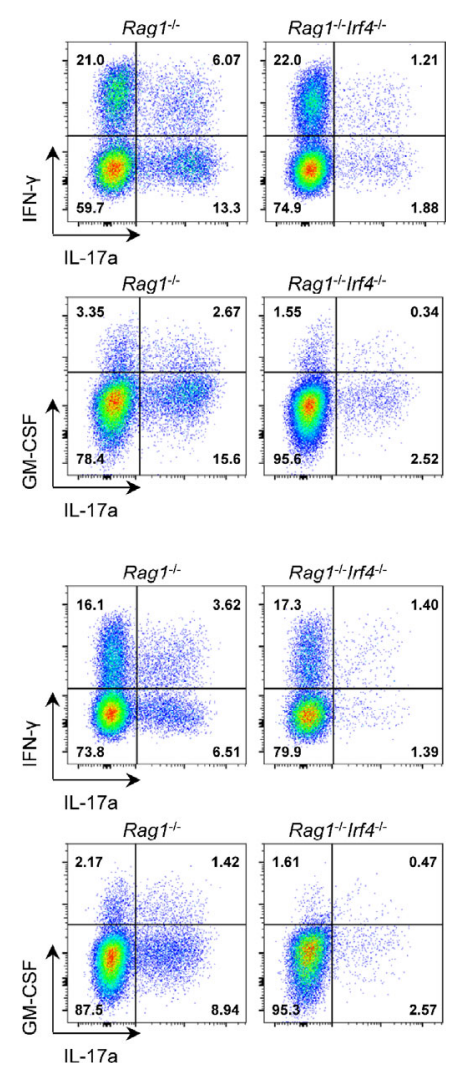

FIGURE 4 | Multiple Th17 cell subsets but not bona fide Th1 cells are critically dependent on the expression of functional IRF4 in Rag $1^{-/-}$mice with established T

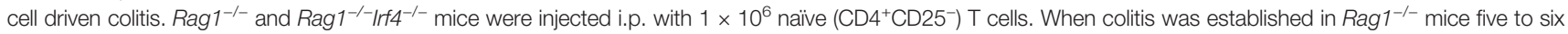

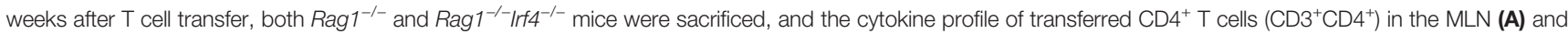
in the CLP (B) was analyzed by intracellular flow cytometry after ex vivo restimulation. Frequencies of IFN- $\gamma^{+} \mid \mathrm{L}-17 \mathrm{a}^{-}$, IFN- $\gamma^{+} \mid \mathrm{L}-17 \mathrm{a}^{+}$, IFN- $\gamma^{-} \mathrm{IL}-17 \mathrm{a}^{+}$(upper panel) and GM-CSF ${ }^{+} \mathrm{LL}-17 \mathrm{a}^{-} \mathrm{GM}-\mathrm{CSF}^{+} \mathrm{IL}-17 \mathrm{a}^{+} \mathrm{GM}-\mathrm{CSF}^{-} \mathrm{IL}-17 \mathrm{a}^{+}$(lower panel) expressing cell populations within the $\mathrm{CD} 4^{+} \mathrm{T}$ cell pool were analyzed. One representative flow cytometry plot is shown for every experimental group. Data are combined from two individual experiments $\left(\operatorname{Rag} 1^{-/-} \mathrm{n}=7 ; \operatorname{Rag}^{-/-} \mid \mathrm{r} f 4^{-/-} \mathrm{n}=8\right)$. Data were analyzed by Student's $t$ test and are shown as mean \pm SEM. ns, not significant. ${ }^{*} p<0.05$.

not diminished in numbers, colonic cDC2 might be functionally affected (e.g. migratory abilities) upon IRF4 deletion and at least partially contribute to compromised induction of colitogenicity within transferred $\mathrm{T}$ cells.

Collectively, given the hampered colitis formation in $\mathrm{T}$ cell recipient $\mathrm{Rag}^{-/-}$mice lacking IRF4, here we provide data giving crucial mechanistic insight into the molecular mechanisms by showing that IRF4 controls the formation of colitogenic BATFand ROR $\gamma$-dependent Th17 cell subsets in a $\mathrm{T}$ cellextrinsic manner.

\section{DISCUSSION}

Clinical practice in IBD management has profoundly changed upon the availability of targeted therapies. While antibodymediated blockade of the cytokine TNF-alpha represents a mainstay in the management of chronic inflammatory diseases including IBD, the expression of additional cytokines as e.g. IL13 , IL-6, IL-17, and IL-23 has been identified to be highly upregulated within inflamed tissues $(7,52-54)$. While clinical studies demonstrated that inhibition of some of those cytokines is effective at least in certain disease entities, in IBD only IL-23 targeting showed convincing inflammation-reducing effects and hence was approved for this indication (55). Molecularly, IL-23 employs multiple mechanism thereby affecting a series of immune cells to promote immune-mediated tissue inflammation (10-12, 56-58). However, IL-23 is predominately fostering pro-inflammatory $\mathrm{T}$ helper cells that share a common feature, i.e. the expression of IL-17a (10, 59). Hence, the identification of alternative targeting strategies going beyond IL-23 neutralization to contain Th17 cell driven tissue destruction remains a valuable goal for basic research enterprises. Recently, effective targeting of the transcriptional regulator GATA3, which is being widely accepted to promote type 2 tissue immune responses by regulating gene expression on a transcriptional level in multiple immune cell subsets implied in 
the pathogenesis of allergic airway diseases, was reported to be achievable by local application of GATA-3-specific DNAzymes, thereby showing clinical efficacy in asthma patients $(60,61)$. Hence, targeting transcription factors to tackle mucosal inflammation may represent a challenging but putatively rewarding research area also in the context of Th17 mediated tissue inflammation. In the chain of events underlying the initiation of an inflammation cascade, transcription factors act rather upstream and thereby often control pathogenetically and functionally related networks acting across cell type borders. The identification and interference with a potential master switch within the Th17 network would hence represent a major advance for the field of targeted immunotherapy of immune-mediated chronic inflammatory disorders.

Until know, $\mathrm{T}$ cell-intrinsic expression of a series of transcriptional regulators like BATF, ROR $\gamma$ and IRF4 has been identified to be crucial for a $\mathrm{T}$ cell to differentiate into a pro-inflammatory Th17 cell $(39,49,62)$. Interestingly, transcription factors usually regulate multiple milestones within a given cell type both by direct and indirect transcriptional effects. For example, besides regulating the expression of IL-17 cytokine family members directly, BATF is indispensable for continuous $\mathrm{ROR} \gamma$ expression and hence controls through this regulation of the Th17 cell network also indirectly the expression of the IL-23 receptor in T cells $(39,63$, 64). Among Th17 fate regulating transcription factors, especially IRF4 seems to exert crucial functions in a series of $\mathrm{T}$ cell-extrinsic immune cell populations including innate lymphoid cells (ILCs), dendritic cells, and monocytes (16, 19, 65-67). However, the functional role of IRF4 expressed in non$\mathrm{T}$ cells in the context of intestinal inflammation has not gained much attention. We found here in this study that inactivation of IRF4 employing germ line deletion disables IRF4-proficient T cells to mediate disease in a widely accepted $\mathrm{T}$ cell dependent mouse model of acute colitis. Mechanistically, our analyses revealed that the establishment of a Th17 inducing cytokine milieu in the colon, as e.g. upregulated IL-1ß and IL-6 expression, required IRF4 while for IL-23 expression it was not. While the reduction of IL- $1 ß$ and IL- 6 might be sufficient to explain hampered Th17 differentiation, the missing regulation of IL-23 expression in colitic tissue appears at first sight puzzling for two reasons: First, IRF4 dependent cDC2s have been described to be the major producer of IL-23 among DCs and thereby putatively impacting Th17 cell differentiation directly $(16,19)$. Second, to account for the hampered proliferation of differentiated Th17 cells as one possible explanation for the reduced colitis manifestation appears at first sight rather unlikely given the widely accepted dominant role of IL-23 in this context through the provision of critical survival and expansion signals especially for IL-23 receptor expressing Th17 cells $(12,13)$. However, although we have not tested that possibility directly, in the light of downregulated $\mathrm{BATF} / \mathrm{ROR} \gamma \mathrm{t}$ both known to regulate IL-23 receptor expression $\mathrm{T}$ cells primed in IRF4-deficient $\mathrm{Rag1}^{-/-}$mice in fact may lack IL-23R expression on their cell surface. Thereby $\mathrm{T}$ cells were unable to receive proliferation-promoting effects from IL-23, overall providing an explanation for their mitigated colitogenicity. In this scenario and supported by our data, colonic IL-23 levels are mounted by cells functioning at least in this respect independent of IRF4, resulting in similar total IL-23 tissue levels. In fact, $\mathrm{T}$ cells selectively lacking IL-23R through genetic inactivation similarly fail to mediate colitis in this model system (12). Hence, despite indistinguishable provision of IL-23, effects dependent on the IL-23/IL-23R interaction on T cells appear to be extinguished in the absence of IRF4 in non-T cells due to virtually absent IL23R expression on developing effector T cells. In fact, IL-23R expression analysis within total colon tissues revealed strikingly reduced levels presumably due to decreased total T cell numbers in the colon but most likely also reflecting reduced IL-23 receptor copies expressed by a single cLP T cell. Future studies certainly need to further investigate the question which molecular signals derived from the remaining and putatively functionally compromised IRF4-deficient cDC2s may directly or indirectly account for proper induction of IL23 receptor expressing, colitogenic Th17 cells. Interestingly, IL6 was shown to induce both BATF and ROR $\gamma$ in a STAT3dependent manner (42). Given reduced IL-6 tissue levels, IL-6 expression might be dependent on the presence of IRF4 within myeloid cells both in the MLN and/or CLP $(16,19)$. Hence, IRF4 deficiency-related reduction of IL- 6 expression might additionally undermine Th17 differentiation. This scenario of IL-6 driven Th17 cell differentiation may be clinically relevant given the clinical observation that some patients do not respond to IL-23 blockade despite a Th17 dominated mucosal inflammation in situ. However, this hypothesis will require vigorous testing in the future especially in the light of rather moderate results that studies investigating the efficacy of an IL-6 blocking antibody (tocilizumab) in $\operatorname{IBD}$ reported $(68,69)$.

Hence, based on our current study, global interference with IRF4 expression and consecutively IRF4-dependent pathways might emerge as a promising therapeutic option gain control especially in those sub-cohorts of IBD patients suffering from continuous intestinal inflammation refractory to all currently available and clinically approved treatment regimens. Due to its documented, dual colitogenic role both in $\mathrm{T}$ cells and non- $\mathrm{T}$ cells, IRF4 targeting may be in this regard a very attractive molecular target to limit intestinal inflammation by inhibiting both development and functionality of Th17 cells.

Since the identification of the precise IRF4-dependent non-T cell immune cell(s) and/or signaling pathways putatively regulating $\mathrm{T}$ cell driven colitis was not the focus of this study and in fact will require already planned future experimentation, we can only speculate on that at this point. Although IRF4 has been clearly shown to impact ILC biology (65), antibody mediated ablation of ILC in fact leads to an aggravation of colitis (data not shown) and as previously published $(50,51)$ indicating that hampered ILC functionality is not likely to underlie the colitis protection observed in the absence of IRF4. In addition, in this study we provide experimental data that IRF4 deficiency does not alter the pool of colonic ILC1, ILC2 or ILC3 on $\mathrm{Rag}^{-/-}$background. While this does not formally exclude an 
ILC-mediated mechanism underlying colitis protection in the absence of IRF4, our and published data, however, are not in favor of the conclusion that regulation of ILC function is here involved. Based on the currently available literature, among myeloid cells known to express IRF4 the functionality of APC may appear to be most likely regulated in an IRF4-dependent manner and by this control colitogenic T cell differentiation (15, $16,44)$. In $\mathrm{CD}_{11} \mathrm{~b}^{+} \mathrm{cDCs}$, i.e. $\mathrm{cDC} 2$, IRF4 regulates migration to (70) and survival within mucosal tissues $(16,19)$. As elaborated above in respect to the biology of IL-23, cDC2 cells are in part dependent on IRF4 as confirmed in this study and have been put forward to be critical in Th17 cell biology due to its preferential expression of IL-23 among cDCs $(16,19,71,72)$. Future studies including the usage of $\mathrm{cDC}$-specific deletor mice, i.e. genetically engineered mice expressing cre recombinase under the control of the promotor of $Z b t b 46$ crossed to mice carrying a conditionally targeted IRF4 allele will be required to address that question (73, 74). Similarly, distinct functions within monocytes and monocyte-derived cells have been shown to be regulated by IRF4 as e.g. the ability to cross-present cell-associated antigens to $\mathrm{CD}^{+} \mathrm{T}$ cells (66), fine-tuning TLR signaling (75), cytokine expression (76) or development and functionality of immunosuppressive myeloid cell populations (77). Here, with the help of novel genetic model systems, future studies need to decipher cell-type specific roles of IRF4 within ontogenetically distinct $\mathrm{CDC}$ and monocyte-derived cell populations in the context of colitis.

Collectively, our study unequivocally demonstrates that IRF4 expressed in non-T cells is a positive regulator of Th17 cell mediated colitis. Given the T cell-intrinsic role of IRF4 in driving Th17 cell differentiation in vitro (62) and also in the context of colitis in vivo (32), our data support the conclusion that inactivation of IRF4 universally protects against Th17 mediated colitis and suggest that strategies to interfere with IRF4 gene expression are of potential great interest to harness acute intestinal inflammation.

\section{DATA AVAILABILITY STATEMENT}

The raw data supporting the conclusions of this article will be made available by the authors, without undue reservation.

\section{REFERENCES}

1. Kaser A, Zeissig S, Blumberg RS. Inflammatory bowel disease. Annu Rev Immunol (2010) 28:573-621. doi: 10.1146/annurev-immunol-030409-101225

2. Sartor RB. Genetics and environmental interactions shape the intestinal microbiome to promote inflammatory bowel disease versus mucosal homeostasis. Gastroenterology (2010) 139(6):1816-9. doi: 10.1053/j.gastro.2010.10.036

3. Castro F, de Souza HSP. Dietary Composition and Effects in Inflammatory Bowel Disease. Nutrients (2019) 11(6):1-22. doi: 10.3390/nu11061398

4. Shale M, Schiering C, Powrie F. CD4(+) T-cell subsets in intestinal inflammation. Immunol Rev (2013) 252(1):164-82. doi: 10.1111/imr.12039

5. Smids C, Horjus Talabur Horje CS, Drylewicz J, Roosenboom B, Groenen MJM, van Koolwijk E, et al. Intestinal T Cell Profiling in Inflammatory Bowel Disease: Linking T Cell Subsets to Disease Activity and Disease Course. J Crohns Colitis (2018) 12(4):465-75. doi: 10.1093/ecco-jcc/jjx160

\section{ETHICS STATEMENT}

The animal study was reviewed and approved by government of Lower Franconia.

\section{AUTHOR CONTRIBUTIONS}

VB, TV, PK, TK, and HK performed the experiments. VB analyzed and interpreted the data together with $\mathrm{KH}$ and TV. $\mathrm{KE}$ and $\mathrm{CN}$ established and performed the immunofluorescence stainings with the help of TV. $\mathrm{MH}$ performed the histopathological analyses. CL, LA, SW, and DD gave important advice and provided crucial reagents. MN gave important advice and helped with the interpretation and critical discussion of the results. $\mathrm{KH}$ directed the study and wrote the manuscript together with VB and valuable input from all authors. All authors contributed to the article and approved the submitted version.

\section{FUNDING}

This study was supported by the Collaborative Research Centers 1181 (DFG-CRC1181, project $\mathrm{B} 05$, to $\mathrm{KH}$ and project $\mathrm{A} 07$, to DD), TRR241 (DFG-CRC/TR241 A08 to both CN \& KH), TRR221 project B03 to KH, DFG/DU548/5-1 to DD, DFG/HI 849/4-1 and SPP1656/ HI 849/5-1 (both to KH).

\section{ACKNOWLEDGMENTS}

We thank I. Klaußner and S. Lukat for excellent technical assistance and Dr. Kristina Scheibe for valuable advice.

\section{SUPPLEMENTARY MATERIAL}

The Supplementary Material for this article can be found online at: https://www.frontiersin.org/articles/10.3389/fimmu.2020.590893/ full\#supplementary-material

6. Tindemans I, Joosse ME, Samsom JN. Dissecting the Heterogeneity in T-Cell Mediated Inflammation in IBD. Cells (2020) 9(1):1-6. doi: 10.3390/cells9010110

7. Holtta V, Klemetti P, Sipponen T, Westerholm-Ormio M, Kociubinski G, Salo H, et al. IL-23/IL-17 immunity as a hallmark of Crohn's disease. Inflamm Bowel Dis (2008) 14(9):1175-84. doi: 10.1002/ibd.20475

8. Hueber W, Sands BE, Lewitzky S, Vandemeulebroecke M, Reinisch W, Higgins PD, et al. Secukinumab, a human anti-IL-17A monoclonal antibody, for moderate to severe Crohn's disease: unexpected results of a randomised, double-blind placebo-controlled trial. Gut (2012) 61(12):1693700. doi: 10.1136/gutjnl-2011-301668

9. Targan SR, Feagan FB, Vermeire S, Panaccione R, Melmed GY, Blosch C, et al. Mo2083 A Randomized, Double-Blind, Placebo-Controlled Study to Evaluate the Safety, Tolerability, and Efficacy of AMG 827 in Subjects With Moderate to Severe Crohn's Disease. Gastroenterology (2012) 143(3):e26. doi: 10.1053/ j.gastro.2012.07.084 
10. Bunte K, Beikler T. Th17 Cells and the IL-23/IL-17 Axis in the Pathogenesis of Periodontitis and Immune-Mediated Inflammatory Diseases. Int J Mol Sci (2019) 20(14):1-24. doi: 10.3390/ijms20143394

11. Hue S, Ahern P, Buonocore S, Kullberg MC, Cua DJ, McKenzie BS, et al. Interleukin-23 drives innate and $\mathrm{T}$ cell-mediated intestinal inflammation. J Exp Med (2006) 203(11):2473-83. doi: 10.1084/jem.20061099

12. Ahern PP, Schiering C, Buonocore S, McGeachy MJ, Cua DJ, Maloy KJ, et al. Interleukin-23 drives intestinal inflammation through direct activity on $\mathrm{T}$ cells. Immunity (2010) 33(2):279-88. doi: 10.1016/j.immuni.2010.08.010

13. McGeachy MJ, Chen Y, Tato CM, Laurence A, Joyce-Shaikh B, Blumenschein $\mathrm{WM}$, et al. The interleukin 23 receptor is essential for the terminal differentiation of interleukin 17-producing effector $\mathrm{T}$ helper cells in vivo. Nat Immunol (2009) 10(3):314-24. doi: 10.1038/ni.1698

14. Schmitt H, Billmeier U, Dieterich W, Rath T, Sonnewald S, Reid S, et al. Expansion of IL-23 receptor bearing TNFR2+ $\mathrm{T}$ cells is associated with molecular resistance to anti-TNF therapy in Crohn's disease. Gut (2019) 68 (5):814-28. doi: 10.1136/gutjnl-2017-315671

15. Schlitzer A, McGovern N, Ginhoux F. Dendritic cells and monocyte-derived cells: Two complementary and integrated functional systems. Semin Cell Dev Biol (2015) 41:9-22. doi: 10.1016/j.semcdb.2015.03.011

16. Schlitzer A, McGovern N, Teo P, Zelante T, Atarashi K, Low D, et al. IRF4 transcription factor-dependent $\mathrm{CD} 11 \mathrm{~b}+$ dendritic cells in human and mouse control mucosal IL-17 cytokine responses. Immunity (2013) 38(5):970-83. doi: 10.1016/j.immuni.2013.04.011

17. Coombes JL, Siddiqui KR, Arancibia-Carcamo CV, Hall J, Sun CM, Belkaid Y, et al. A functionally specialized population of mucosal CD103+ DCs induces Foxp3+ regulatory $\mathrm{T}$ cells via a TGF-beta and retinoic acid-dependent mechanism. J Exp Med (2007) 204(8):1757-64. doi: 10.1084/jem.20070590

18. Muzaki AR, Tetlak P, Sheng J, Loh SC, Setiagani YA, Poidinger M, et al. Intestinal CD103CD11b dendritic cells restrain colitis via IFN-gammainduced anti-inflammatory response in epithelial cells. Mucosal Immunol (2015) 9:336-51. doi: 10.1038/mi.2015.64

19. Persson EK, Uronen-Hansson H, Semmrich M, Rivollier A, Hagerbrand K, Marsal J, et al. IRF4 transcription-factor-dependent CD103(+)CD11b(+) dendritic cells drive mucosal $\mathrm{T}$ helper 17 cell differentiation. Immunity (2013) 38(5):958-69. doi: 10.1016/j.immuni.2013.03.009

20. Mashayekhi M, Sandau MM, Dunay IR, Frickel EM, Khan A, Goldszmid RS, et al. CD8alpha(+) dendritic cells are the critical source of interleukin-12 that controls acute infection by Toxoplasma gondii tachyzoites. Immunity (2011) 35(2):249-59. doi: 10.1016/j.immuni.2011.08.008

21. Arnold IC, Mathisen S, Schulthess J, Danne C, Hegazy AN, Powrie F. CD11c monocyte/macrophages promote chronic Helicobacter hepaticus-induced intestinal inflammation through the production of IL-23. Mucosal Immunol (2015) 9:352-63. doi: 10.1038/mi.2015.65

22. Bain CC, Mowat AM. Macrophages in intestinal homeostasis and inflammation. Immunol Rev (2014) 260(1):102-17. doi: 10.1111/imr.12192

23. Bain CC, Scott CL, Uronen-Hansson H, Gudjonsson S, Jansson O, Grip O, et al. Resident and pro-inflammatory macrophages in the colon represent alternative context-dependent fates of the same Ly6Chi monocyte precursors. Mucosal Immunol (2013) 6(3):498-510. doi: 10.1038/mi. 2012.89

24. Schlitzer A, Ginhoux F. Organization of the mouse and human DC network. Curr Opin Immunol (2014) 26:90-9. doi: 10.1016/j.coi.2013.11.002

25. Guilliams M, Ginhoux F, Jakubzick C, Naik SH, Onai N, Schraml BU, et al. Dendritic cells, monocytes and macrophages: a unified nomenclature based on ontogeny. Nat Rev Immunol (2014) 14(8):571-8. doi: 10.1038/nri3712

26. Hildner K, Edelson BT, Purtha WE, Diamond M, Matsushita H, Kohyama M, et al. Batf3 deficiency reveals a critical role for CD8alpha+ dendritic cells in cytotoxic T cell immunity. Science (2008) 322(5904):1097-100. doi: 10.1126/ science. 1164206

27. Ginhoux F, Liu K, Helft J, Bogunovic M, Greter M, Hashimoto D, et al. The origin and development of nonlymphoid tissue CD103+ DCs. J Exp Med (2009) 206(13):3115-30. doi: 10.1084/jem.20091756

28. Schiavoni G, Mattei F, Sestili P, Borghi P, Venditti M, Morse HC,3, et al. ICSBP is essential for the development of mouse type I interferon-producing cells and for the generation and activation of CD8alpha(+) dendritic cells. J Exp Med (2002) 196(11):1415-25. doi: 10.1084/jem.20021263
29. Hacker C, Kirsch RD, Ju XS, Hieronymus T, Gust TC, Kuhl C, et al. Transcriptional profiling identifies Id 2 function in dendritic cell development. Nat Immunol (2003) 4(4):380-6. doi: 10.1038/ni903

30. Tamura T, Tailor P, Yamaoka K, Kong HJ, Tsujimura H, O'Shea JJ, et al. IFN regulatory factor -4 and -8 govern dendritic cell subset development and their functional diversity. J Immunol (2005) 174(5):2573-81. doi: 10.4049/ jimmunol.174.5.2573

31. Suzuki S, Honma K, Matsuyama T, Suzuki K, Toriyama K, Akitoyo I, et al. Critical roles of interferon regulatory factor 4 in CD11bhighCD8alphadendritic cell development. Proc Natl Acad Sci U S A (2004) 101(24):89816. doi: 10.1073/pnas.0402139101

32. Mudter J, Amoussina L, Schenk M, Yu J, Brustle A, Weigmann B, et al. The transcription factor IFN regulatory factor-4 controls experimental colitis in mice via T cell-derived IL-6. J Clin Invest (2008) 118(7):2415-26. doi: 10.1172/ JCI33227

33. Powrie F, Leach MW, Mauze S, Caddle LB, Coffman RL. Phenotypically distinct subsets of $\mathrm{CD} 4+\mathrm{T}$ cells induce or protect from chronic intestinal inflammation in C. B-17 scid mice. Int Immunol (1993) 5(11):1461-71. doi: 10.1093/intimm/5.11.1461

34. Ostanin DV, Bao J, Koboziev I, Gray L, Robinson-Jackson SA, KosloskiDavidson $\mathrm{M}$, et al. T cell transfer model of chronic colitis: concepts, considerations, and tricks of the trade. Am J Physiol Gastrointest Liver Physiol (2009) 296(2):G135-46. doi: 10.1152/ajpgi.90462.2008

35. Becker C, Fantini MC, Neurath MF. High resolution colonoscopy in live mice. Nat Protoc (2006) 1(6):2900-4. doi: 10.1038/nprot.2006.446

36. Punkenburg E, Vogler T, Buttner M, Amann K, Waldner M, Atreya R, et al. Batf-dependent Th17 cells critically regulate IL-23 driven colitis-associated colon cancer. Gut (2015) 65(7):1139-50. doi: 10.1136/gutjnl-2014-308227

37. Erben U, Loddenkemper C, Doerfel K, Spieckermann S, Haller D, Heimesaat $\mathrm{MM}$, et al. A guide to histomorphological evaluation of intestinal inflammation in mouse models. Int J Clin Exp Pathol (2014) 7(8):4557-76.

38. Ullrich E, Abendroth B, Rothamer J, Huber C, Buttner-Herold M, Buchele V, et al. BATF-dependent IL-7RhiGM-CSF+ T cells control intestinal graftversus-host disease. J Clin Invest (2018) 128(3):916-30. doi: 10.1172/JCI89242

39. Schraml BU, Hildner K, Ise W, Lee WL, Smith WA, Solomon B, et al. The AP1 transcription factor Batf controls T(H)17 differentiation. Nature (2009) 460 (7253):405-9. doi: 10.1038/nature08114

40. Leppkes M, Becker C, Ivanov II, Hirth S, Wirtz S, Neufert C, et al. RORgamma-expressing Th17 cells induce murine chronic intestinal inflammation via redundant effects of IL-17A and IL-17F. Gastroenterology (2009) 136(1):257-67. doi: 10.1053/j.gastro.2008.10.018

41. Hildner K, Punkenburg E, Abendroth B, Neurath MF. Immunopathogenesis of IBD: Batf as a Key Driver of Disease Activity. Dig Dis (2016) 34(Suppl 1):40-7. doi: 10.1159/000447281

42. Durant L, Watford WT, Ramos HL, Laurence A, Vahedi G, Wei L, et al. Diverse targets of the transcription factor STAT3 contribute to T cell pathogenicity and homeostasis. Immunity (2010) 32(5):605-15. doi: 10.1016/j.immuni.2010.05.003

43. Mittrucker HW, Matsuyama T, Grossman A, Kundig TM, Potter J, Shahinian $\mathrm{A}$, et al. Requirement for the transcription factor LSIRF/IRF4 for mature B and T lymphocyte function. Science (1997) 275(5299):540-3. doi: 10.1126/ science.275.5299.540

44. Cerovic V, Bain CC, Mowat AM, Milling SW. Intestinal macrophages and dendritic cells: what's the difference? Trends Immunol (2014) 35(6):270-7. doi: 10.1016/j.it.2014.04.003

45. Tamoutounour S, Henri S, Lelouard H, de Bovis B, de Haar C, van der Woude CJ, et al. CD64 distinguishes macrophages from dendritic cells in the gut and reveals the Th1-inducing role of mesenteric lymph node macrophages during colitis. Eur J Immunol (2012) 42(12):3150-66. doi: 10.1002/eji.201242847

46. Weber B, Saurer L, Schenk M, Dickgreber N, Mueller C. CX3CR1 defines functionally distinct intestinal mononuclear phagocyte subsets which maintain their respective functions during homeostatic and inflammatory conditions. Eur J Immunol (2011) 41(3):773-9. doi: 10.1002/eji.201040965

47. Zigmond E, Varol C, Farache J, Elmaliah E, Satpathy AT, Friedlander G, et al. Ly6C hi monocytes in the inflamed colon give rise to proinflammatory effector cells and migratory antigen-presenting cells. Immunity (2012) 37(6):1076-90. doi: 10.1016/j.immuni.2012.08.026 
48. Szabo SJ, Kim ST, Costa GL, Zhang X, Fathman CG, Glimcher LH. A novel transcription factor, T-bet, directs Th1 lineage commitment. Cell (2000) 100 (6):655-69. doi: 10.1016/s0092-8674(00)80702-3

49. Ivanov II, McKenzie BS, Zhou L, Tadokoro CE, Lepelley A, Lafaille JJ, et al. The orphan nuclear receptor RORgammat directs the differentiation program of proinflammatory IL-17+ T helper cells. Cell (2006) 126(6):1121-33. doi: 10.1016/j.cell.2006.07.035

50. Brasseit J, Kwong Chung CKC, Noti M, Zysset D, Hoheisel-Dickgreber N, Genitsch V, et al. Divergent Roles of Interferon-gamma and Innate Lymphoid Cells in Innate and Adaptive Immune Cell-Mediated Intestinal Inflammation. Front Immunol (2018) 9:23. doi: 10.3389/fimmu.2018.00023

51. Qiu J, Guo X, Chen ZM, He L, Sonnenberg GF, Artis D, et al. Group 3 innate lymphoid cells inhibit T-cell-mediated intestinal inflammation through aryl hydrocarbon receptor signaling and regulation of microflora. Immunity (2013) 39(2):386-99. doi: 10.1016/j.immuni.2013.08.002

52. Neurath MF. Cytokines in inflammatory bowel disease. Nat Rev Immunol (2014) 14(5):329-42. doi: 10.1038/nri3661

53. Adegbola SO, Sahnan K, Warusavitarne J, Hart A, Tozer P. Anti-TNF Therapy in Crohn's Disease. Int J Mol Sci (2018) 19(8):1-21. doi: 10.3390/ ijms19082244

54. D'Haens G, Van Deventer S, Van Hogezand R, Chalmers D, Kothe C, Baert F, et al. Endoscopic and histological healing with infliximab anti-tumor necrosis factor antibodies in Crohn's disease: A European multicenter trial. Gastroenterology (1999) 116(5):1029-34. doi: 10.1016/s0016-5085(99)70005-3

55. Hanzel J, D'Haens GR. Anti-interleukin-23 agents for the treatment of ulcerative colitis. Expert Opin Biol Ther (2020) 20(4):399-406. doi: 10.1080/ 14712598.2020.1697227

56. Buonocore S, Ahern PP, Uhlig HH, Ivanov II, Littman DR, Maloy KJ, et al. Innate lymphoid cells drive interleukin-23-dependent innate intestinal pathology. Nature (2010) 464(7293):1371-5. doi: 10.1038/nature08949

57. Izcue A, Hue S, Buonocore S, Arancibia-Carcamo CV, Ahern PP, Iwakura Y, et al. Interleukin-23 restrains regulatory $\mathrm{T}$ cell activity to drive $\mathrm{T}$ cell-dependent colitis. Immunity (2008) 28(4):559-70. doi: 10.1016/j.immuni.2008.02.019

58. Griseri T, Arnold IC, Pearson C, Krausgruber T, Schiering C, Franchini F, et al. Granulocyte Macrophage Colony-Stimulating Factor-Activated Eosinophils Promote Interleukin-23 Driven Chronic Colitis. Immunity (2015) 43(1):187-99. doi: 10.1016/j.immuni.2015.07.008

59. Harrington LE, Hatton RD, Mangan PR, Turner H, Murphy TL, Murphy KM, et al. Interleukin 17-producing CD4+ effector $\mathrm{T}$ cells develop via a lineage distinct from the T helper type 1 and 2 lineages. Nat Immunol (2005) 6 (11):1123-32. doi: 10.1038/ni1254

60. Krug N, Hohlfeld JM, Kirsten AM, Kornmann O, Beeh KM, Kappeler D, et al. Allergen-induced asthmatic responses modified by a GATA3-specific DNAzyme. N Engl J Med (2015) 372(21):1987-95. doi: 10.1056/ NEJMoa1411776

61. Greulich T, Hohlfeld JM, Neuser P, Lueer K, Klemmer A, Schade-Brittinger C, et al. A GATA3-specific DNAzyme attenuates sputum eosinophilia in eosinophilic COPD patients: a feasibility randomized clinical trial. Respir Res (2018) 19(1):55. doi: 10.1186/s12931-018-0751-x

62. Brustle A, Heink S, Huber M, Rosenplanter C, Stadelmann C, Yu P, et al. The development of inflammatory $\mathrm{T}(\mathrm{H})-17$ cells requires interferon-regulatory factor 4. Nat Immunol (2007) 8(9):958-66. doi: 10.1038/ni1500

63. Betz BC, Jordan-Williams KL, Wang C, Kang SG, Liao J, Logan MR, et al. Batf coordinates multiple aspects of $\mathrm{B}$ and $\mathrm{T}$ cell function required for normal antibody responses. J Exp Med (2010) 207(5):933-42. doi: 10.1084/ jem. 20091548

64. Murphy TL, Tussiwand R, Murphy KM. Specificity through cooperation: BATF-IRF interactions control immune-regulatory networks. Nat Rev Immunol (2013) 13(7):499-509. doi: 10.1038/nri3470
65. Mohapatra A, Van Dyken SJ, Schneider C, Nussbaum JC, Liang HE, Locksley RM. Group 2 innate lymphoid cells utilize the IRF4-IL-9 module to coordinate epithelial cell maintenance of lung homeostasis. Mucosal Immunol (2016) 9 (1):275-86. doi: 10.1038/mi.2015.59

66. Briseno CG, Haldar M, Kretzer NM, Wu X, Theisen DJ, Kc W, et al. Distinct Transcriptional Programs Control Cross-Priming in Classical and MonocyteDerived Dendritic Cells. Cell Rep (2016) 15(11):2462-74. doi: 10.1016/ j.celrep.2016.05.025

67. Nam S, Lim JS. Essential role of interferon regulatory factor 4 (IRF4) in immune cell development. Arch Pharm Res (2016) 39(11):1548-55. doi: $10.1007 /$ s12272-016-0854-1

68. Atreya R, Billmeier U, Rath T, Mudter J, Vieth M, Neumann H, et al. First case report of exacerbated ulcerative colitis after anti-interleukin-6R salvage therapy. World J Gastroenterol (2015) 21(45):12963-9. doi: 10.3748/ wjg.v21.i45.12963

69. Szeto MC, Yalcin MD, Khan A, Piotrowicz A. Successful Use of Tocilizumab in a Patient with Coexisting Rheumatoid Arthritis and Ulcerative Colitis. Case Rep Immunol (2016) 2016:7562123. doi: 10.1155/2016/7562123

70. Bajana S, Roach K, Turner S, Paul J, Kovats S. IRF4 promotes cutaneous dendritic cell migration to lymph nodes during homeostasis and inflammation. J Immunol (2012) 189(7):3368-77. doi: 10.4049/ jimmunol.1102613

71. Gao Y, Nish SA, Jiang R, Hou L, Licona-Limon P, Weinstein JS, et al. Control of T helper 2 responses by transcription factor IRF4-dependent dendritic cells. Immunity (2013) 39(4):722-32. doi: 10.1016/j.immuni.2013.08.028

72. Williams JW, Tjota MY, Clay BS, Vander Lugt B, Bandukwala HS, Hrusch CL, et al. Transcription factor IRF4 drives dendritic cells to promote Th2 differentiation. Nat Commun (2013) 4:2990. doi: 10.1038/ncomms3990

73. Satpathy AT, Kc W, Albring JC, Edelson BT, Kretzer NM, Bhattacharya D, et al. Zbtb46 expression distinguishes classical dendritic cells and their committed progenitors from other immune lineages. J Exp Med (2012) 209 (6):1135-52. doi: 10.1084/jem.20120030

74. Loschko J, Schreiber HA, Rieke GJ, Esterhazy D, Meredith MM, Pedicord VA, et al. Absence of MHC class II on cDCs results in microbial-dependent intestinal inflammation. J Exp Med (2016) 213(4):517-34. doi: 10.1084/ jem.20160062

75. Negishi H, Ohba Y, Yanai H, Takaoka A, Honma K, Yui K, et al. Negative regulation of Toll-like-receptor signaling by IRF-4. Proc Natl Acad Sci U S A (2005) 102(44):15989-94. doi: 10.1073/pnas.0508327102

76. Yamamoto M, Kato T, Hotta C, Nishiyama A, Kurotaki D, Yoshinari M, et al. Shared and distinct functions of the transcription factors IRF4 and IRF8 in myeloid cell development. PloS One (2011) 6(10):e25812. doi: 10.1371/ journal.pone.0025812

77. Nam S, Kang K, Cha JS, Kim JW, Lee HG, Kim Y, et al. Interferon regulatory factor 4 (IRF4) controls myeloid-derived suppressor cell (MDSC) differentiation and function. J Leukoc Biol (2016) 100(6):1273-84. doi: 10.1189/jlb.1A0215-068RR

Conflict of Interest: The authors declare that the research was conducted in the absence of any commercial or financial relationships that could be construed as a potential conflict of interest.

Copyright (c) 2021 Buchele, Konein, Vogler, Kunert, Enderle, Khan, Büttner-Herold, Lehmann, Amon, Wirtz, Dudziak, Neurath, Neufert and Hildner. This is an open-access article distributed under the terms of the Creative Commons Attribution License (CC BY). The use, distribution or reproduction in other forums is permitted, provided the original author(s) and the copyright owner(s) are credited and that the original publication in this journal is cited, in accordance with accepted academic practice. No use, distribution or reproduction is permitted which does not comply with these terms. 